\title{
DEVELOPERS' PERSPECTIVES ON TRANSIT-ORIENTED DEVELOPMENT IN EDMONTON, ALBERTA
}

\author{
by \\ Trevor McPherson \\ B.A. (Hon), University of Alberta, 2017 \\ A Major Research Paper \\ Presented to Ryerson University \\ in partial fulfilment of the requirements for the degree of \\ Master of Planning \\ in \\ Urban Development
}

Toronto, Ontario, Canada

(C) Trevor McPherson 2019 


\section{Author's Declaration for Electronic Submission of a MRP}

I hereby declare that I am the sole author of this MRP. This is a true copy of the MRP, including any required final revisions.

I authorize Ryerson University to lend this paper to other institutions or individuals for the purpose of scholarly research.

I further authorize Ryerson University to reproduce this MRP by photocopying or by other means, in total or in part, at the request of other institutions or individuals for the purpose of scholarly research.

I understand that my MRP may be made electronically available to the public. 


\title{
DEVELOPERS' PERSPECTIVES ON TRANSIT-ORIENTED DEVELOPMENT IN EDMONTON, ALBERTA
}

(C) Trevor McPherson, 2019

\author{
Master of Planning \\ in \\ Urban Development \\ Ryerson University
}

\begin{abstract}
Edmonton is currently implementing a plan to significantly expand its light rail transit network. Transit expansion is part of a larger plan to encourage transit-oriented development (TOD) around new and existing transit stations and precipitate a shift towards more dense, efficient land use. Transit technology and routes were then selected, in part, based on their perceived ability to facilitate TOD, and the City has also created the TOD Guidelines and created the TOD Manager position to advance their land use goals. This research includes interviews with 6 developers who are currently undertaking large TOD projects to understand their perceptions of TOD as an investment in the Edmonton, and how effectively municipal decisions have facilitated TOD. The TOD Manager was interviewed, as he plays a critical role in facilitating TOD in Edmonton, as was a planner from the City of Edmonton to provide insight into TOD from a planning perspective and the development approvals process.
\end{abstract}

Key words: urban planning, transit-oriented development (TOD), light rail transit (LRT), Edmonton 


\section{LIST OF TABLES}

Table 1: Factors Affecting Land Use Change With Rapid Transit 9

Table 2: Suggested Criteria to Maximize the Success of TOD 9

Table 3: Edmonton's Transit-Oriented Development Strategy 15

Table 4: Factors Affecting Land Use Change With Rapid Transit 18

Table 5: Suggested Criteria to Maximize the Success of TOD 19 


\section{LIST OF APPENDICES}

Appendix 1: Terms of Reference $\quad 60$

Appendix 2: Redevelopment Areas $\quad 60$

Appendix 3: Station Area Map and LRT Network Map 64 


\section{TABLE OF CONTENTS}

$\begin{array}{ll}1.0 \text { Introduction } & 1\end{array}$

2.0 Literature Review

2.1 Transit-Oriented Development 3

2.2 Facilitating TOD $\quad 5$

$\begin{array}{ll}2.3 \text { Development Corporations and TOD Authorities } & 10\end{array}$

$\begin{array}{ll}3.0 \text { Methodology } & 14\end{array}$

3.1 Research Question $\quad 14$

$\begin{array}{ll}3.2 \text { Methods } & 14\end{array}$

3.1 Participants 16

$\begin{array}{ll}3.3 \text { Theoretical Framework } & 18\end{array}$

$\begin{array}{ll}3.4 \text { Limitations } & 20\end{array}$

4.0 Findings and Analysis $\quad 21$

$\begin{array}{ll}4.1 \text { Background } & 21\end{array}$

4.2 Transit Technology and Route Selection $\quad 24$

4.3 TOD Guidelines and Area Redevelopment Plans 28

4.4 Social and Physical Site Conditions 33

$\begin{array}{ll}\text { 4.5 Market Conditions } & 37\end{array}$

4.6 The Blatchford Redevelopment and Municipal Development Corporations 42

4.7 TOD Manager and Municipal Administration 46

$\begin{array}{ll}5.0 \text { Summary of Findings } & 54\end{array}$

$\begin{array}{ll}\text { 6.0 Recommendations } & 58\end{array}$

$\begin{array}{ll}7.0 \text { Appendices } & 60\end{array}$

$\begin{array}{ll}7.1 \text { Appendix } 1 \text { - Terms of Reference } & 60\end{array}$

7.2 Appendix 2 - Redevelopment Areas $\quad 60$

7.3 Appendix 3 - Station Area Map and LRT Network Map 64

$\begin{array}{ll}\text { 8.0 References } & 66\end{array}$ 


\subsection{Introduction}

This research aims to understand how effectively the City of Edmonton is facilitating transit-oriented development (TOD) along existing and planned transit routes and precipitating a shift to more dense, efficient land use patterns. Edmonton City Council adopted the Long-Term LRT Network Plan in 2009. The plan would significantly expand the LRT system by extending the existing line further north and south, and adding 4 new lines; however, it now appears that full build out will include 4 lines total (City of Edmonton, 2012; Appendix 3). This ambitious transit expansion plan has been undertaken not only to improve mobility, but also to shift the city toward more urban, efficient land use patterns, thereby creating a more sustainable municipal tax base (City of Edmonton, 2012; Stolte, 2017).

Important decisions surrounding LRT network expansion related to transit technology, route selection, planning policy, and municipal administration have been made to facilitate the goal of transit-oriented development and creating a more dense, efficient city. Currently, there are some large TOD proposals, some projects proceeding through the approvals process, and others in the early stages of construction, but transit expansion and efforts to facilitate TOD remain in their early stages so we cannot yet determine the efficacy of Edmonton's efforts based on completed TOD projects. Failed or floundering efforts to facilitate TOD and to precipitate a shift in land use patterns have been experienced in comparable cities. Additionally, some decisions surrounding the LRT network expansion, specifically those regarding route selection and transit technology, have proven controversial as they will disrupt entrenched land use patterns and lifestyles. 
Given the significance of this planning initiative to the future of the city and the potential to better understand the efficacy of the city's efforts while in the early stages of implementation, the topic is worthy of study. This research will then seek to understand how developers' in Edmonton perceive the potential of TOD as an investment opportunity and the efficacy of Edmonton's efforts to facilitate TOD. I will do this by interviewing developers who are currently undertaking large TOD projects in Edmonton. This will include multi-building projects of 3 or more buildings that are located in the TOD station areas as identified in the TOD Guidelines (Appendix 3). These broad criteria would include every major TOD project in Edmonton, however, four major TOD projects will be excluded as they are part of much larger redevelopment projects and are being undertaken with an exceptional amount of public-sector involvement and are not representative of most TOD in the city, which brings the total number of developers included to 7. Two City of Edmonton employees will also be interviewed due to the relevance of their work to TOD in Edmonton. 


\subsection{Literature Review}

\subsection{Transit-Oriented Development}

Transit-oriented development (TOD) is high density, mixed-use development concentrated around transit stations designed in such a way that facilitates more compact, efficient land use patterns, and the viability of public transit, cycling, and walking as primary modes of transportation (Knight \& Trygg, 1977; Cervero, 1984; Cervero \& Kockelman, 1997; Ratner \& Goetz, 2012; Hess \& Lombardi, 2004). While there is some debate on whether transit-land use formations must precipitate a mode shift to be considered truly transit-oriented development, the above definition will be used throughout this research (Belzer \& Autler, 2002). TOD was initially purported to provide a number of land use benefits ranging from reduced personal vehicle usage and ownership, greater mobility choice, and reduced infrastructure costs to economic development, more affordable housing, and greater household disposable income (Richmond, 1996; Hess \& Lombardi, 2004). Many of the more modest benefits have proven true, such as reduced personal vehicle usage and ownership, greater mobility choice, and reduced infrastructure costs (Cervero, 1984; Richmond, 1996; Holtzclaw et al., 2002; James, 2009). However, TOD's potential to encourage economic development, increase household disposable income, or improve housing affordability have proven incorrect, or, in the case of housing affordability, actually made worse by TOD (Holtzclaw et al., 2002; Rene et al., 2016; Mathur \& Ferrel, 2013; James, 2009; Utter 2009; Duncan, 2010). Housing unaffordability and income stratification are currently significant concerns in many major urban centres, but in smaller cities addressing the inefficiency of low-density land use patterns is a more pressing issue and TOD provides a solution (OECD, 2016). Transit-oriented land use is common in European and Asian 
cities due to their high density built form being established before automobiles, their large populations and small land areas, and their tendency toward more interventionist planning regimes, however, interest has increased in Canadian, American and Australian cities due to generational preference shifts toward more urban and sustainable lifestyles, renewed public investment in transit infrastructure, the need to mitigate traffic congestion, and the need for more efficient land use (Ratner \& Goetz, 2012; Utter, 2009).

Canadian, American and Australian cities all have largely low density, auto-oriented land use patterns, and other cities provide useful examples when examining what may hinder TOD in a city like Edmonton. Often, there remains a gap in the demand for and supply of TOD caused by both market and policy failure (Utter, 2009; Guthrie \& Fan, 2016; Levine, 2012). Divergent public and private sector views on TOD are likely the source, as municipalities often view the initial transit investment as providing both the necessary infrastructure and an increase in land values, while the private sector views TOD as complicated and therefore risky and believes the public sector needs to help mitigate those risks (Utter, 2009; Duncan, 2010; Guthrie \& Fan, 2016; James, 2009; Wood, 2009). Developers in different cities typically identify similar constraints to TOD: fragmented land titles and speculation, lack of demand for TOD, high costs, onerous regulation, and lack of leadership (Utter, 2009; Guthrie \& Fan, 2016; James, 2009; Jones, 2006; Higgins et al. 2014; Tan et al. 2014). Difficulty assembling a piece of land large enough to ensure a critical mass of development that can create a distinct place is a common problem facing new TOD, and this is compounded by speculation assuming increased land values due to new transit and development (Utter, 2009; James, 2009; Higgins et al., 2014; Duncan, 2010). The problem is twofold, as the increase in land costs is accompanied by 
developers' preference to assess an investment's potential by examining comparable investments, which limits innovative development in growing markets (Utter, 2009; Higgins et al., 2014). Lack of comparables feeds into the perceived lack of a market for TOD, or, even when there is thought to be demand, reluctance to be the one to test its strength (Utter, 2009; Guthrie \& Fan, 2016). Uncertainty and high development costs incentivize TOD in areas with high incomes, so developers can charge premium prices to recoup costs and ensure profits large enough to justify the risk, and this has been found to contribute to unaffordability in TOD areas (Utter, 2009; Guthrie \& Fan, 2016; Rene et al., 2016; Higgins et al., 2014; Duncan, 2010). Developers also identify a lack of effective TOD-specific policy that is integrated with other plans and policies (Utter, 2009; Guthrie \& Fan, 2016; Higgins et al., 2014). Compounding these factors is community opposition to TOD, whether it be due to the exacerbation of housing affordability issues in larger urban centres, or concerns about traffic, parking, lifestyle disruption, as it typically is in more suburban locations (Guthrie \& Fan, 2016; Sim et al., 2015; Noland et al. 2017). Leadership by and coordination between the public, private, and non-profit sectors to address the issues listed above and craft a TOD strategy is also considered essential to properly facilitate TOD (Utter, 2009; James, 2009, Guthrie and Fan, 2016; Ratner and Goetz, 2012; Curtis, 2008).

\subsection{Facilitating TOD}

American cities have tended toward passive strategies that focus only on infrastructure, creating planning policy and regulations, or providing incentives to comply with optional planning guidelines and they have often failed to have the desired effect (Cervero, 1994; Belzer \& Poticha, 2009; Duncan, 2010; Lee and Sener, 2017; Schuetz et al., 2018). Californian cities 
have failed to properly facilitate TOD in many instances, and much of the TOD that does exist has failed to reduce automobile usage to the full extent possible. In both the Bay Area and Greater Los Angeles automobiles have remained competitive with transit due to TOD being primarily residential and the cities' dispersed employment base, and, in San Diego, condominiums in station areas with poor transit-land use integration have been valued significantly less (Cervero, 1994; Duncan, 2010). Another planning failure in Los Angeles was its station area plans. Despite the TOD-supportive zoning, the plans were implemented in addition to existing regulation, creating a system of "multi-layered zoning and potential incompatibility across plans" at a number of stations to varying degrees, which has been seen in other cities as well (Higgins et. al, 2014; Jones, 2006; Schuetz et al., 2018). As a result, minimal TOD has occurred in ideal, centrally located station areas with TOD-compatible uses in a city with a strong real estate market (Schuetz. et al., 2018). Minneapolis, similar to Edmonton, is a low-density, auto-oriented city that is reinvesting in public transit, and plans for the infrastructure and associated development to be transformative (Guthrie and Fan, 2016). Early research assessing development around transit stations in Minneapolis found the impact of new and proposed transit lines to be insignificant, which suggests that their approach of simply building transit is not enough to encourage TOD and that corresponding policy is required (Hurst and West, 2014; Leach, 2004). However, an overly-permissive regulatory environment is not effective either. Houston has low-density, auto-oriented land use patterns and is known for not having a zoning bylaw. Analysis examining development along the city's first LRT line that opened in 2004 shows there are few examples of TOD in the city (Lee and Sener, 2017). Cities must be careful not to become overly flexible regarding regulation, as research has shown that if 
zoning regulations are seen as sufficiently malleable they are effectively inconsequential (Levine, 2012). These are only some examples and many other American cities have demonstrated that a strictly regulatory focused approach is not enough (Belzer \& Poticha, 2009; Lee and Sener, 2017; Levine and Inam, 2004; Levine, 2012; Duncan, 2010).

Strong real estate markets are also essential for TOD, and stations need to be located in such market or station areas need to be made more attractive through public investment (Cervero \& Seskin, 1995; Lee and Sener, 2017; Wood, 2009). Locating stations in areas with strong real estate markets that can support high density development and where efficient transit can be provided often requires selecting transit routes running through historic, centrally located neighborhoods with positive social conditions (Cervero \& Seskin, 1995; Levine and Inam, 2004; Schuetz. et al., 2018; Fleissig \& Carlton, 2009; Lavery \& Kanaroglou, 2012; Utter, 2009; Guthrie \& Fan, 2016; Rene et al., 2016). Transit stations that are well-integrated with the urban context, providing ease of access and improved user experience, and connect the station area to active transit networks have shown to be successful, as these features improve market viability in the surrounding area (Cervero \& Kockelman, 1997; Wood, 2009; Belzer \& Poticha, 2009). Transit technology is also an important consideration, as some types of transit are believed to have greater potential to facilitate TOD (Cervero, 1984; Cervero, 1994; Arrington, 2003; Xao \& Porter-Nelson, 2016). Heavy-rail systems have greater development potential but are significantly more expensive and for cities with dispersed land use patterns would constitute an over-building of infrastructure (Cervero, 1984). Combining the greater development potential of heavy-rail with the failure of LRT to delivery on high development expectations in cities in the past, there is some skepticism of the potential for TOD in smaller cities with entrenched 
suburban lifestyles like Edmonton (Cervero, 1984; Richmond, 1998; Sim et al., 2015)

Skepticism regarding the potential of bus rapid transit (BRT) to induce the land use shift sought from TOD also remains, and developers often reiterate that the lingering stigma of buses will limit their use, and therefore TOD potential, and that they have a preference for fixed guideway transit (Vuchic, 2007; Cervero \& Dai, 2014). However, it is disputed in the literature whether BRT actually has less development potential (Vuchic, 2007; Cervero \& Dai, 2014; Levinson et al. 2002). Coordination of these public investments with private investment is essential, but this has proven difficult to do effectively in many cities (Wood, 2009; Belzer \& Poticha, 2009; Tan et al. 2014). Effective investment and regulation require coordination within the public sector between various departments, and between the public sector and the private sector to create a TOD-conducive environment (Utter, 2009; James, 2009, Guthrie and Fan, 2016; Ratner and Goetz, 2012; Curtis, 2008; Wood, 2009; Duncan, 2010).

Many researchers have contributed to the extensive TOD scholarship that identifies and clarifies the factors that lead to effective TOD, and some have created frameworks based on their analysis of established literature. One example is Higgins' et al. (2014) 'Factors Affecting Land Use Change With Rapid Transit'. The framework examined 10 essential academic works related to TOD and the conditions and policies required to produce effective TOD, many of which are referenced elsewhere in this literature review. Higgins et al. (2014) identified 6 factors required to facilitate TOD and precipitate a land use shift: transit accessibility, positive growth and demand, positive social conditions, positive physical conditions, land availability, and complementary planning. 


\begin{tabular}{|c|l|}
\hline \multicolumn{2}{|c|}{ Factors Affecting Land Use Change With Rapid Transit (Higgins et al., 2014) } \\
\hline Transit Accessibility & $\begin{array}{l}\text { Ease of access to transit and to various destinations from } \\
\text { transit stations, as well as physical ease of access facilitated } \\
\text { by integrating stations within their surroundings. }\end{array}$ \\
\hline $\begin{array}{c}\text { Positive Growth and } \\
\text { Demand }\end{array}$ & $\begin{array}{l}\text { Economic and population growth that will create demand for } \\
\text { housing. }\end{array}$ \\
\hline $\begin{array}{c}\text { Positive Social Conditions } \\
\text { Positive Physical } \\
\text { Conditions }\end{array}$ & $\begin{array}{l}\text { Low crimes rates, high quality public facilities and services, } \\
\text { relative wealth and high employment, perception of } \\
\text { desirability. }\end{array}$ \\
\hline Land Availability & $\begin{array}{l}\text { High quality streetscaping, public amenities, and enjoyable } \\
\text { physical environment. }\end{array}$ \\
\hline Complimentary Planning & $\begin{array}{l}\text { a willingness from the public sector to facilitate land } \\
\text { assembly. }\end{array}$ \\
\hline
\end{tabular}

These six factors outline important considerations and preconditions that planners and governments must create to facilitate TOD. Evan Jones (2006) created a similar framework that focuses more narrowly on specific issues municipalities should focus on and tools they can use. The framework, called 'Suggested Criteria to Maximize the Success of TOD', states that areas of focus should be planning, governance, urban finance, and leadership.

\begin{tabular}{|c|l|}
\hline \multicolumn{2}{|c|}{ Suggested Criteria to Maximize the Success of TOD (Jones, 2006) } \\
\hline Planning & $\begin{array}{l}\text { Improve approval certainty and timeliness, create flexible TOD-specific } \\
\text { planning regulations that are supported by other plans, attain land } \\
\text { acquisition powers, and better integrate of TOD relevant authorities. }\end{array}$ \\
\hline Governance & $\begin{array}{l}\text { Integrate relevant municipal and provincial/state agencies, create public } \\
\text { sector agencies specifically to facilitate TOD, and have the municipality } \\
\text { take an active role in facilitating TOD rather than simply applying } \\
\text { regulation. }\end{array}$ \\
\hline
\end{tabular}




\begin{tabular}{|c|l|}
\hline Urban Finance & $\begin{array}{l}\text { Directing public work projects to TOD projects, target these investments } \\
\text { to where private investment is being made, and ask for developer } \\
\text { contributions to these projects. }\end{array}$ \\
\hline Leadership & $\begin{array}{l}\text { Private, public, and non-profit sector leadership is necessary for TOD to } \\
\text { be successful. }\end{array}$ \\
\hline
\end{tabular}

\subsection{Development Corporations and TOD Authorities}

Factors of success and common impediments were established early in TOD research and have been repeatedly reaffirmed in various cities globally (Knight \& Trygg, 1977; Cervero, 1994; Cervero, 1984; Cevero \& Dai, 2014; Utter, 2009; Tan et al., 2014; Geen, 2016; Guthrie \& Fan, 2016). Addressing these criteria has proven difficult in many municipalities with many early TOD attempts failing or requiring extensive public sector funding and involvement (Cevero, 1984; Richmond, 1998). Establishing a discrete entity tasked with overseeing broad TOD goals, mitigating impediments, and coordinating stakeholders are now a common, and often necessary, implementation step (Fleissig \& Carlton, 2009; Utter, 2009; Tan et al., 2014; Geen, 2016; Guthrie \& Fan, 2016). Successful examples of this have been provided in some cities by using various forms of municipal development agencies that include government departments from multiple levels of government, private sector representatives, and non-profits to facilitate TOD (Cevero \& Murakami, 2009; Utter, 2009; James, 2009; Guthrie \& Fan, 2016; Ratner \& Goetz, 2012; Curtis, 2008; Tan et al., 2014; Geen, 2016). Generally, these types of organizations fall into three categories: transit-development agencies, intergovernmental agencies, and municipal development agencies.

Transit-development agencies are agencies that manage the transit system and develop the land surrounding their station in partnership with developers and have arguably proven the 
most successful. Singapore and Hong Kong utilize similar models in which the transit agency coordinates with a strong central government to obtain land and pursues development in partnership with the private sector (Yeng \& Lew, 2009; Cevero \& Murakami, 2009; Yaro, December 2017) Hong Kong Mass Transit Railway Corporation (MTRC) undertakes 'Rail+Property' projects, which are exceptional high density mixed use developments at transit stations, and are extremely successful examples of value capture (Cevero \& Murakami, 2009). Property development is a significant part of Hong Kong MTRC as the management of the transit system, and profits from their development have funded transit extensions (Cevero \& Murakami, 2009). New York's Metropolitan Transit Authority also works with the municipal government and enters in joint development deals to build TOD (Schneider, 2004).

Intergovernmental agencies are those that are primarily led by municipal or regional governments and strive to coordinate all the relevant departments from various levels of government as well as necessary non-government partners. For example, Denver began to expand its regional rail transit system in 1995 and sought to encourage TOD around new and existing stations. To accomplish this, Denver coordinated 4 governments and government agencies, created extensive TOD specific plans and policies, and created the Denver Regional Council of Governments, which describes itself as "as a resource for planners, developers, policy-makers and citizens who are interested in the implementation of Transit-Oriented Development"' (Ratner \& Goetz, 2012). Across the United States, similar agencies exist in various formations, partnering with state government, county government, neighboring cities, regional planning organizations, and redevelopment corporations (Cervero, 2004). Similar to Denver, Perth, Australia expanded its regional rail transit system in the mid 1990s, and as part of 
their Network City Plan created a TOD committee that includes members from state government's planning, infrastructure, public transport and development agencies, which jointly establishes policy priorities and implementation strategies for approximately 100 transit hubs in the region (Curtis, 2008). Perth's most successful TOD was undertaken outside this framework by a municipal development agency (Curtis, 2008). Brisbane, Australia has also used municipal development agency called Urban Renewal Brisbane with great success (James, 2009). The agency was tasked with creating partnerships between developers, government, and community networks, and facilitated the development of 76 hectares of underutilized land (James, 2009). At the state level, the South Bank Corporation is a "landowner, facilitator, and public realm manager" that now oversees many projects, including TOD, and is known for transforming a former World Expo site into “one of Australia’s great public places” (James, 2009). Transit agencies have also doubled as development agencies in Brisbane, as Queensland Transit oversaw the development of the Varsity Station Village TOD (James, 2009).

Intergovernmental and transit-development agencies are more common and necessary in larger urban centres, especially in Asia and the United States due to their size and the nature of governance structures (Fleissig \& Carlton, 2009). In smaller Canadian cities with less complicated governance structures, like Edmonton, a more simple format could be used. Calgary provides a useful example, as it operates in a nearly identical economic and regulatory context. The City utilizes a municipal land corporation to facilitate development in a large redevelopment area that will constitute TOD - the land corporation is not used specifically for TOD like in other cities - which has shown to be exceptionally effective at achieving criteria necessary for facilitating development generally and meeting the criteria outlined literature for encouraging 
TOD (Green, 2016). According to planners, the development agency has also ensured planning goals are achieved and plans are consistent with development industry realities (Green, 2016). Calgary also has a team within the planning department dedicated to facilitating TOD by taking control of most relevant planning policy and coordinating the necessary departments within municipal administration and between administration and developers, which is a common approach in many cities (Fleissig \& Carlton, 2009; Blair, 2009) 


\subsection{Methodology}

\subsection{Research Question}

How do developers undertaking large transit-oriented development (TOD) projects view the City of Edmonton's TOD Strategy and how has it affected their investment decisions?

\subsection{Methods}

Primary data will be collected for this research through interviews. Interviews provide an opportunity to obtain a fulsome understanding of developers' opinions and understandings of a relatively complex issue, and how their investment decisions are affected (Neuman and Robson, 2018). While interviews are typically used for more subjective questions and this research seeks to address questions about policy and infrastructure, it is how developers' perceive the market and regulatory context that dictates investment decisions, again, making interviews the appropriate method (Neuman and Robson, 2018).

Analysis will focus on what I will refer to as the City of Edmonton's TOD Strategy. While not officially considered a coherent strategy, the TOD Strategy includes the four most significant actions taken by administration to facilitate TOD. First, is the selection of a transit technology not previously used in the city on new transit lines, more specifically, Bombardier's Flexity Freedom trains. These trains will be referred to as 'low-floor trains'. This technology was selected to provide better integration with the urban context and ease of access to the station while providing a fixed guideway, as opposed to bus rapid transit, as these attributes facilitate TOD (City of Edmonton, 2012 March; City of Edmonton, 2009 May; ). Route selection for the new transit lines was the second element of the strategy. Initially, the Valley Line the line was to run directly west connecting two important nodes: West Edmonton Mall and the University of 
Alberta. Later, a less direct route was chosen that ran along important roadways through parts of the city most suitable for intensification and touched upon large, underutilized pieces of land. Third, was the creation of the Transit-Oriented Development Guidelines (2012), which are the primary policy document governing transit-oriented development (TOD). The document provides extensive and specific guidelines for every existing and planned station area, and includes a station area typology, Land Use and Intensity Guidelines, Building and Site Design Guidelines, and Public Realm and Urban Design Guidelines (Transit Oriented Development Guidelines, 2012). The policy is intended to be used by "public stakeholders, developers, city administration and city council" to guide the creation or amendment of Station Area Plans, Area Redevelopment Plans, and applications and approvals for site-specific rezonings. Area Redevelopment Plans (ARPs) are statutory plans in Alberta, so they largely attend to the same issues across plans and cities; those being, land use, density and height, built form, the street network, and the public realm. Some key TOD locations have new ARPs in place that consider the TOD Guidelines, while others have yet to be updated. At all important sites TOD is expected to be achieved through developer-initiated rezonings, as explicitly stated in the TOD Guidelines, and some of these sites have been successful in attracting major development applications as well. Various policies that must be considered generally also apply to TOD projects, but only the TOD Guidelines apply solely to TOD. The fourth element of the TOD Strategy was the creation of the TOD Manager position. These are the four components that are analyzed in this research and are what form the TOD Strategy.

\section{Edmonton's Transit-Oriented Development Strategy}

Transit Technology Selection of low-floor LRT as it is perceived to be superior in creating conditions for TOD. 


\begin{tabular}{|c|l|}
\hline Route Selection & $\begin{array}{l}\text { Selection of new LRT routes based on their being perceived } \\
\text { as optimal for facilitating TOD. }\end{array}$ \\
\hline TOD Guidelines & $\begin{array}{l}\text { Creation of the TOD Guidelines, which serve as the primary } \\
\text { TOD policy document and guide developers', municipal } \\
\text { administration, and city council decisions surrounding Area } \\
\text { Redevelopment Plans and rezoning applications. }\end{array}$ \\
\hline TOD Manager & Creation of the TOD Manager position to facilitate TOD. \\
\hline
\end{tabular}

\subsection{Participants}

Eight interviews were conducted with 6 developers and 2 municipal employees. Guy Boston, the Transit Oriented Development Manager at the City of Edmonton, was interviewed as the creation of his position was an element of the TOD Strategy making his perspective essential to the research. Andrew McLellan, Principle Planner for Core and Mature Communities at the City of Edmonton, has worked on key TOD projects and was included to provide a better understanding of TOD in Edmonton from a planning perspective and due to his knowledge of the development approvals process for major TOD projects. Both the public sector participants were included to better understand the City of Edmonton's approach to TOD, but the focus of the research is developers' perspectives on TOD. Developer interviews were to include the developers of all major TOD projects located in TOD Station Areas according to the TOD Guidelines that do not include exceptional policies, development conditions, or level of public sector involvement. This exclusion criteria of 'exceptional policies, development conditions, or level of public sector involvement' refers to 4 projects that have a substantial amount of public financing, operate under tax increment financing schemes, involved design competitions, or required atypical negotiations and approvals; those being, Ice District, The Quarters, Blatchford, 
and the Exhibition Lands. These projects are mentioned by participants and are discussed as potential competition to the projects being researched, and locations and descriptions of these projects can be found in Appendix 2. Interview participants were selected on the basis that they worked for companies undertaking such projects and their knowledge and familiarity with the project in question and so their names and positions are relevant to the research and have been included. The ethics review process made clear to participants' that their name and position will be stated, they will be quoted directly, and the research will be made publicly available. Participants:

- Guy Boston, Transit Oriented Development Manager at the City of Edmonton.

- Andrew McLellan, Principal Planner for Core and Mature Communities at the City of Edmonton.

- Raj Dhunna, the Chief Operating Officer of Regency Developments regarding Holyrood Gardens at Holyrood Station.

- Calvin McCourt, Director of Development at Morguard Investments regarding Bonnie Doon Town Centre at Bonnie Doon Station.

- Stuart Craig, Vice President of Planning and Development at RioCan regarding Mill Woods Town Centre at Mill Woods Station and Jasper Gates at 149th Street Station.

- Ryan Smith, President of Inhouse by Beaverbrook regarding West Block at 142 Street Station.

- Warren Ollis, Development Manager at Brookfield regarding the Muttart District at Stadium Station. 
- A representative of Nearctic and Rockwell Property Group about Strathern Heights at Strathern Station.

- ProCura did not consent to have the information provided used in this research. Their project is Century Park at Century Park Station.

\subsection{Theoretical Framework}

Two pieces of scholarship on transit-oriented development will form the theoretical framework from which interview questions are derived: Primary Factors Affecting Land Use Change by Higgins et al. (2014) and Suggested Criteria to Maximize the Success of TOD by Jones (2006). Both these works reiterate the factors identified as essential to facilitating TOD throughout the literature. Higgins et al. (2014) examined 10 key academic works analyzing factors affecting land use change around transit stations and identified 6 factors that were present in these works and are listed below.

\begin{tabular}{|c|l|}
\hline \multicolumn{2}{|c|}{ Factors Affecting Land Use Change With Rapid Transit (Higgins et al., 2014) } \\
\hline Transit Accessibility & $\begin{array}{l}\text { Ease of access to transit and to various destinations from } \\
\text { transit stations, as well as physical ease of access facilitated } \\
\text { by integrating stations within their surroundings. }\end{array}$ \\
\hline $\begin{array}{c}\text { Positive Growth and } \\
\text { Demand }\end{array}$ & $\begin{array}{l}\text { Economic and population growth that will create demand for } \\
\text { housing. }\end{array}$ \\
\hline $\begin{array}{c}\text { Positive Social Conditions } \\
\text { Positive Physical } \\
\text { Conditions }\end{array}$ & $\begin{array}{l}\text { Low crimes rates, high quality public facilities and services, } \\
\text { relative wealth and high employment, perception of } \\
\text { desirability. }\end{array}$ \\
\hline $\begin{array}{c}\text { Land Availability } \\
\text { physical environment. }\end{array}$ & $\begin{array}{l}\text { Large, inexpensive, parcels of land near transit stations, and/or } \\
\text { a willingness from the public sector to facilitate land } \\
\text { assembly. }\end{array}$ \\
\hline Complimentary Planning & Policies designed to facilitate TOD and encourage transit \\
\hline
\end{tabular}


usage.

Some questions attempted to determine whether developers' perceive these necessary preconditions for TOD as being already established, or, if relevant, the extent to which the TOD Strategy attempts to or succeeds in creating them. Given that this research is focused on planning, the 'complimentary planning' category of the Higgins et al (2014) framework will be probed further and these questions will be derived from Jones' Suggested Criteria to Maximize the Success of TOD (2006). Jones' framework focuses specifically on planning and municipal policies that will facilitate TOD rather than broader preconditions for success. Understanding the way in which these two frameworks will fit together, with the Higgins et al. (2014) framework being used to identify the necessary preconditions for TOD and Jones (2006) framework criteria being effectively subsumed under the 'complimentary planning' category to further probe that issue, is essential to understand the methodology.

\begin{tabular}{|c|l|}
\hline \multicolumn{2}{|c|}{ Suggested Criteria to Maximize the Success of TOD (Jones, 2006) } \\
\hline Planning & $\begin{array}{l}\text { Improve approval certainty and timeliness, create flexible TOD-specific } \\
\text { planning regulations that are supported by other plans, attain land } \\
\text { acquisition powers, and better integrate of TOD relevant authorities. }\end{array}$ \\
\hline Governance & $\begin{array}{l}\text { Integrate relevant municipal and provincial/state agencies, create public } \\
\text { sector agencies specifically to facilitate TOD, and have the municipality } \\
\text { take an active role in facilitating TOD rather than simply applying } \\
\text { regulation. }\end{array}$ \\
\hline Urban Finance & $\begin{array}{l}\text { Directing public work projects to TOD projects, target these investments } \\
\text { to where private investment is being made, and ask for developer } \\
\text { contributions to these projects. }\end{array}$ \\
\hline Leadership & $\begin{array}{l}\text { Private, public, and non-profit sector leadership is necessary for TOD to } \\
\text { be successful. }\end{array}$ \\
\hline
\end{tabular}


Using this methodology, questions were created that covered the following topics: the TOD Manager position; transit technology, route selection, and accessibility; social and physical site conditions; coordination of public and private investment; land availability and assembly; planning policy and development approvals; growth, demand, and market conditions; and the City's approach to TOD, major public-sector led developments, and the potential for a municipal development corporation.

\subsection{Limitations}

There are two limitations of this research: limited public sector input with most participants being developers, and one developer was not willing to have the information provided used in this research. Limiting the scope of this project to focus primarily developers with minimal public sector input was done in part so the research remained feasible. Nonetheless, understanding the perspective of the private sector is essential, as it is developers ultimately create the built form and must work within the framework created by planners. However, it must be acknowledged that private sector actors are motivated by profit and what maximizes a specific developer's profits may not, in fact, be what is necessary to effectively facilitate high quality transit-oriented development or be good planning. Also, given that only one of the developers that met the selection criteria declined to release the information provided, I do not believe that the developers' choice not to participate is a significant limitation. 


\subsection{Findings and Analysis}

The following section will provide findings from the interviews and the necessary context and analysis. Findings are organized into categories that represent the most significant findings. Question topics not addressed below did not provide relevant findings. Also, it is important to note that the terms 'intensification' and 'infill' are used interchangeably by some participants.

\subsection{Background}

Land use patterns in Edmonton are shaped by the post-war, modernist planning practices that managed periods of rapid growth caused by the highly cyclical regional economy and the accompanying population influxes that caused sharp reductions in vacancy rates, at times to the point of crisis, requiring new housing and roads to be built quickly (Smith, 2007). Foundations for a shift in the nature of urban growth came in the late 1970's when the citizens' group Urban Reform Group Edmonton (URGE) successfully halted the construction of an inner-city freeway and secured investment for Edmonton's Light Rail Transit (LRT) system, which was completed in 1978 (Lightbody, 2006). The LRT system gradually expanded over the following decades with a series of small extensions being completed in 1981, 1989, 1991, 1998, 2006, and 2009 (City of Edmonton). In 2009, the Long-Term LRT Network Plan was adopted which aimed to significantly expand the LRT system by extending the existing line further north and south, adding 2 new lines, and beginning study for a third line (City of Edmonton, 2012).

Potential for TOD along the original Capital Line LRT was thought to be high by both the public and private sector, as over half of the line was funded by developers who perceived significant benefit to themselves (Cervero, 1984). Edmonton's unsuccessful attempts at encouraging a higher density built form along the line began soon after it was completed in 1982, and continued 
to be unsuccessful through the 1990s despite multiple adjustments to their strategy

(Querengesser, 2018). In the early 2000s another attempt was made at Belvedere station with the Station Pointe TOD where a tax increment financing system was implemented at the station area and significant resources were invested in improving the physical conditions of the site, but the poor social conditions of the area, incompatible land uses, and poor transit integration contributed to generally poor development conditions and the site has stagnated (Querengesser, 2018). This was commented on by both public sector participants.

"An ongoing [failure] at Station Pointe for example. Yeah, big dreams for that. Location, location, location; it's up against an active rail line, it's right across the street from an abature and heavy industrial, it's an interesting part of town. Did the location and the vision really match? No. We need to be strategic and we need to prioritize around where we think the biggest and best successes are. Hindsight is 20/20.” - Guy Boston (TOD Manager)

"I think it might just be an over assumption that transit is the only factor that's needed to spur development. You know, Station Pointe, it's by an LRT station and a lot of work was done, but if you look at the surrounding area and the broader area, there's a lot of things about it that aren't necessarily appealing to a developer and transit not going to make up for that entirely and make it instantly a desirable place to develop." - Andrew McLellan (Urban Planner)

As the Capital Line was extended further south an opportunity for TOD arose at the site of a shopping mall (Crowther, 2018). When a developer stepped forward to undertake the type of large, high density project the City desired, the LRT extension was expedited to Century Park (Crowther, 2018). Around this time other proposals came forward with Strathearn Heights (Nearctic and Rockwell) initially being rezoned in 2008 and the original iteration of West Block around the same time (Stolte, 2017). Century Park was put on hold after the global recession of 2008, in the following years the original developer of the West Block became financially 
incapable of completing the project, and Strathearn Heights has progressed slowly since its initial rezoning (Kent, 2017).

In 2013, ProCura revised their plans for Century Park and has since revived the project (Crowther, 2018). At approximately this time key elements of the City's TOD Strategy were adopted or implemented such as approving the Long Term LRT Network Plan, deciding to use low-floor LRT for the Valley Line, and the creation of the TOD Guidelines (City of Edmonton, 2012; City of Edmonton, 2012 March; City of Edmonton, 2009 May). As stated previously, the TOD Guidelines are the primary policy document that governs TOD and were created based on the assumption that there would be numerous incoming TOD proposals.

"The guidelines were put together imagining there's just going to be this onslaught of TOD. Here comes everybody and everything, so we need to have some guidelines so we can at least be consistent as they come with their individual applications. It's been sporadic at best." - Guy Boston (TOD Manager)

Only recently has TOD gained some momentum in Edmonton: West Block was purchased by another developer and revived in 2015, Mill Woods Town Centre and Holyrood Gardens went through their approvals process in 2017, the Muttart TOD was approved in 2018, and Jasper Gates and Bonnie Doon Town Centre are currently proceeding through the approvals process. While no large TOD projects have been completed, some are under construction, and all the developers of large projects have received approvals and will be able to provide insight into their interactions with the City and how their decision to move forward with a large investment was affected by the TOD Strategy.

Amongst the developers participating in this research there are two noteworthy dynamics that were prevalent in their responses that are not explored in detail in this research but are 
nonetheless noteworthy. First, is the fact that both RioCan (Stuart Craig) and Morguard (Calvin McCourt) are large developers that operate nationally and internationally respectively, and their approach to development and their view of the Edmonton market is different than the other smaller, local or Alberta-based developers interviewed. Second, is participants' awareness of the protracted and contentious Holyrood Gardens (Regency) public consultations and rezoning process that nearly caused the developer to abandon the project. All participants spoke of the Holyrood Gardens approvals process as an instance from which the City, communities, and developers can learn.

\subsection{Transit Technology and Route Selection}

The first two parts of the City of Edmonton's TOD Strategy as I have identified it were their decisions regarding transit technology and route selection. The low-floor LRT was chosen as it is perceived as being able to create superior conditions for TOD as it improves transit accessibility and physical site conditions by better integrating into its surroundings, as compared to the high-floor LRT used on older LRT lines which require extensive safety and traffic-separation measures. Prior to becoming the TOD Manager, Guy Boston was responsible for LRT Delivery at the City of Edmonton, and prior to that he worked at a private engineering consultancy that was hired by the City of Edmonton to work on the Valley Line LRT, so he has an exceptional understanding of LRT in Edmonton. Regarding the decision to opt for low-floor

\section{LRT Boston stated:}

"Low floor LRT was chosen specifically to fit into the community as opposed to divide the community, to be more of an urban LRT as opposed to a suburban or commuter LRT. The lines that we have built now were built on an old railroad right of way. It's got barbed wire fence and bells and arms and all kinds of stuff that comes with a commuter train. That type has been forced into the community on the south side down 111th and 114th street. It's a challenge from a transportation perspective as well as a fit in urban fit 
perspective. When the city of Edmonton was examining what are they going to do, there was a lot of work that was done around showcasing what's being done in North America and around the world, and the low floor urban LRT was chosen to be the mode that was going to work for what the city of Edmonton envisioned around mobility and changing urban forum...because it would fit into the community much better. They will work with the existing pedestrian and street traffic signals to be a much more seamless." - Guy Boston (TOD Manager)

Boston also explains the reasoning behind route selection for the Valley Line.

"The original plan for the West LRT was from Louis Estates down 87th Avenue, across the river, into the University. It would move a lot of people fast and it'd be cheaper to build. It was changed on the basis of this changing criteria. So when you start to look at how do you select the corridor for an LRT, what's the biggest and highest potential for land use uplift, for getting highest and best use, to implant for changing urban forum for redevelopment perspective, and moving people, the current route for the Valley Line Phase 1 and 2 were chosen based on that criteria, but it was on the basis of it being an urban LRT, a low-floor type LRT." - Guy Boston (TOD Manager)

All but one participant stated that public transit was a prerequisite for their investment, with the Nearctic and Rockwell (Strathearn Heights) being in a unique circumstance where the LRT was routed in part to connected to their already proposed project. Regarding the type of transit, there was a diversity of opinion with some saying low-floor LRT is preferred, some were unconcerned about the type of transit, and others opposed bus rapid transit, stating that a train with a fixed guideway is required to encourage investment and TOD.

"It's a ground level, track-level. We're much happier because it'll integrate much better and people come off the station and can clearly see and move into the site versus to getting off in a tower and having to come down. The intent is obviously not just for people walking, but people riding their bikes and they ride their bike, they can park their bike right next to the station and then the transition to get onto the train as much easier." - Calvin McCourt (RioCan)

"I'm very attracted with the low-floor LRT. I think they make a lot of sense for us because you don't need to build the station platform. And that makes it much more, that 
makes it much more user friendly, much more practical and much and much easier for the developer to work around as well." - Representative of Nearctic and Rockwell

"I think it depends more on, for example, LRT versus BRT. We think there's more value in an LRT line and being adjacent to an LRT station than we do a BRT station. Although BRT stations still have value. It's still a transit stop and it's still a place where people are going to congregate, but a more, you know, I think you'd get more activity around the train station then you do a BRT bus station generally. We're only developing properties that we own or redeveloping properties that we own that are near or adjacent to stations." - Stuart Craig (RioCan)

"Something like BRT would have a pretty negative impact on the site in my mind, at least today. I think the mode that's coming down here, which is more of a street car, it moves somewhat with traffic at certain locations, the design of the tracks are less intrusive. There's no crazy overhead arms with loud signals. It's got a little bit more of a neighborhood feel to it and I think that was probably the key for us, especially right at that corner was understanding that it took away some of the risk of the negative connotations that come with some of the previous LRT that's built in Edmonton or even more so like BRT and bus transit that's functioning today in the city." - Ryan Smith (Beaverbrook)

"For us, the fact that it was LRT was enough for us. We didn't really have a whole lot of knowledge on, on low rail transit, whatever they call it or you know, the kind of street level of transit." - Raj Dhunna (Regency)

"I don't think the type of train would really impact investment in TOD sites at all. Either way, good or bad." - Warren Ollis (Brookfield)

Regarding the route selection of the new Valley Line, developers expressed concern that the route either did not run through parts of the city where there is most likely to demand for higher density development, that it does not run through parts of the city where land will be easy to assemble or questioned whether the order in which new lines are being constructed is ideal. Calvin McCourt (Morguard) and Stuart Craig (RioCan), both Toronto-based developers, were 
unconcerned with the route or sequencing, only that the LRT would take people from their site to central locations.

"I'm not sure if the necessarily all the right stretches of expansion and the sequential order of when they're getting implemented a makes the most sense, but I do think that as the expansions come, they are pretty good at seeing and identifying and making sure that they're their own routes and around areas that will facilitate some of the TOD development later on." - Warren Ollis (Brookfield)

"I'm not sure they necessarily built it in the right areas of town either. I heard an analogy at a real estate conference once: if you want transit to be successful, you've got to build it where the cool kids go. It's where people want to be hanging out. Build it where people want to go. If you build into an area where nobody wants to be right now, where there's no real desire to be, the LRT on its own isn't going to be the single catalyst for transformation in that location." - Ryan Smith (Beaverbrook)

"I'm not sure I quite agree with that with the routes they took [on Valley Line Phase 2] because it's very difficult to assemble the kind of land you would need to drive density at certain stops. My personal sense is that they should have put more thought into how land was going to be assembled on that line. The sheer effort and money involved and energy involved to assemble multiple sites to do high density development and those opportunities are really rare. That's kinda one of the reasons I pointed to [Valley Line Phase 2] is I'm not sure where that's going to happen along that new line. On the Valley Line [Phase 1] you have Strathearn, Mill Woods, Bonnie Doon that gives you four strong locations where there's lots of land. You can drive the density, you can drive the ridership. [Phase 2], I'm not sure that exists." - Raj Dhunna (Regency)

Two developers also commented on the fact that the convenience of driving compared to LRT limits the possibility of a mode shift, which is part of the broader goal of transit expansion and TOD. A local developer spoke to how people experience transit in Edmonton while a Toronto-based developer explicitly stated that they prefer low-floor LRT because it hinders vehicle traffic and encourages a mode shift.

"If you're living in Clareview, the only reason you would ride the LRT is to get downtown or to the University. If you want to go to West Edmonton Mall or if you wanted to the south side or if you want to get anywhere else, it's not really conducive to 
getting there. You'd have to go downtown and transfer to bus, probably transferred to another bus and your commute is an hour and a half to get to the south side when you can get in the car and get there in 20 minutes." - Ryan Smith (Beaverbrook)

"If you have street level that does have a conflict with cars, but the intent is we need to discourage cars so that people will actually use transit." - Calvin McCourt (Morguard)

Overall, the City's investment in rail transit seems to have encouraged development, while the low-floor LRT specifically seems to have been an insignificant detail from the developers' perspective. Developers' distaste for BRT also aligns with findings of other research (Vuchic, 2007; Cervero \& Dai, 2014). Some developers' did prefer the low-floor LRT as it does not detract from the physical site conditions as high-floor LRT does, which has shown to affect market viability of TOD (Cervero \& Kockelman, 1997; Wood, 2009; Belzer \& Poticha, 2009). Developers also expressed concern that the route selection and line sequencing may not be ideal. These concerns are centred on the fact that some dense areas with notable destinations are not being prioritized, and that land assembly may be difficult along some of the routes. While routes and construction sequencing were often chosen due to other valid considerations, such as connecting large redevelopment areas to the transit network, the issue of land assembly is one that has shown to hinder TOD is many cities (Higgins et al., 2014; Jones, 2006).

\subsection{TOD Guidelines and Area Redevelopment Plans}

The TOD Guidelines are the primary TOD policy document and the only TOD-specific policies in place. The guidelines are meant to be used by "public stakeholders, developers, city administration and city council" to guide the creation or amendment of Station Area Plans, Area Redevelopment Plans, and applications and approvals for site-specific rezonings. The guidelines are now 7 years old and, according to Guy Boston's statement quoted on page 23, were intended 
to provide some consistency to what was thought to be an influx of TOD proposals. Boston also explained that the City is trying to better understand how effective the policy is, if at all. Urban planner, Andrew McLellan, also questioned the efficacy of the guidelines.

"I wouldn't say that they're very useful. I don't want to say that they don't have any value, but they're definitely not something that has a lot of teeth and the exact way that they're written, for a lot of situations, it just doesn't really give much guidance at all. For example, if you're around what's identified as an institution/recreation center type station it basically just says there's no guidelines and every station you have to respond to its own context that's around it. So in that case we just review the context around it and then make a judgment call about the application, but the guidelines don't say anything. Sometimes they're lacking, and I would also say that there's a lot of things in the guidelines that are good except that the zoning regulations that currently exist don't require those kinds of things...So, I don't think that they've been super useful. Sometimes they provide good guidance for conversations, but that's about it." - Andrew McLellan (Urban Planner)

Most developers confirmed this view of the guidelines as they said they did not factor into decision-making significantly or expressed indifference.

"We were pretty constrained by the size and shape of our site. Our overall vision kind of fell in line with what a lot of the guidelines said. There wasn't a whole lot in the guidelines or anything that really limited us. It wasn't very challenging to fit within them." - Warren Ollis (Brookfield)

"From our perspective, the TOD Guidelines were synergistic to our future envisioning for the site. So we were already kind of onboard and quite encouraged by them. We were going to move ahead with a lot of things that would have fed right into that because that's what makes us successful. There was a vast array of rich policies that were in front of us and we embraced them all, a lot of them had crossover and kind of doubled up on some of the things, but we had no issue with any of the policies that were in there." - Calvin McCourt (RioCan)

"I think they're good. They're fine. They're not that different than a lot of other cities have put into place quite frankly. We're active in Calgary, Toronto, Ottawa, and we're about to get active in the Vancouver area, and all of the cities have TOD guidelines of one form or another and I would say a lot of them are based on the same principles. They were very 
much part of the application. We were aware of the TOD requirements and we included them in our package and we fashioned our language in our proposal to align with the TOD requirements of the city. And I would say they were a significant part of it." Stuart Craig (RioCan)

"For West block specifically, I would argue that the TOD Guidelines had fairly minimal impact." - Ryan Smith (Beaverbrook)

"They're general. I don't find anything negative. I think they've been well thought through." - Representative of Nearctic and Rockwell

One developer, however, did find the guidelines to be a hindrance in public consultations as it was not properly communicated by the City or understood by the public.

"The Holyrood project it took probably a year longer than it should have and one of the big reasons was misunderstandings around the TOD Guidelines. There was always confusion about what's a large infill site and then the fact that they had designated Holyrood as a neighborhood stop, which is in direct conflict with the fact that it is a large TOD site. Under the neighborhood stop there were certain requirements, and under the TOD Guidelines there were certain requirements, so right off the bat there was confusion over density. The community would often argue, 'Well, this is a neighborhood stop, so there should be this much density' and we would argue, 'No, it's a large infill site, so there should be this much density. There was confusion around some of the nomenclature and labeling that the city had used on both policies. The community or me and my team would read one policy, but then you go read another policy and they contradict each other." - Raj Dhunna (Regency)

Here, the developer is referring to the fact while Holyrood is labeled a neighbourhood stop in the TOD Guidelines, which call for townhouses and low-rise apartments, sites larger than 1 hectare are supposed to follow the Large Site Guidelines outlined a separate document called the Residential Infill Guidelines, which call for high-rise and mid-rise buildings. This developer also spoke more to the community's misunderstanding, administration's failure to communicate, and Council's seeming skepticism of the policy's usefulness. 
"There's a lot of general principles, but the community took them as hard and fast rules whereas the city I think intended some of it to remain flexible and it was meant to be a guideline." - Raj Dhunna (Regency)

"The city didn't really think it through. None of those factors were really built into the TOD Guidelines for a site like ours. We basically created a new policy for large sites. They had kind of a couple of policies that accounted for smaller sites and I can't recall the exact size to the size of the land we had, but our collective site was almost 10 acres and there was no real TOD policy on there." - Raj Dhunna (Regency)

"Some councilors, I believe, thought, "Why did we work on TOD Guidelines if we weren't going to enforce them?' And at the same time argue the fact that, well, it's a guideline, not a policy." - Raj Dhunna (Regency)

According to the developer, these policies also conflicted with the Area Redevelopment Plan (ARP) that was in place. Two developers identified ARPs as begin an obstacle either to their specific project or in areas ideal for intensification that will soon be adjacent to LRT lines and fall within the TOD Station Area zones. For the Muttart TOD (Brookfield), a new ARP was created specifically for the project, and at Mill Woods Town Centre an ARP was created only a few years previous which the developer identified as beneficial to them.

"I'd love to see them start updating more ARPs if they are serious about density...The city should be going in ahead of time and taking on the hassles and headaches so developers shouldn't have to take two years. If you're spending millions of dollars on an LRT line expecting TOD, you might want to go in there as the city a little bit earlier. Try to get ahead of that and address some of the important stops... Some of these ARPs from 1950s or 1960s, those rules no longer apply. They're showing we want to build transit, and the only way to increase ridership on said transit is to get more density in infill communities. So if you're serious about those two things and, you know, there should be more focus on ARPs. They can be smaller, they don't have to be community ranging. They could be on certain lots or areas focusing in on key zones that will definitely go a long way in shaping what the next 10 years or 15 years of Edmonton." - Raj Dhunna (Regency) 
"I think the single biggest [improvement]. Take some time to update along the existing statutory plans that are in place in existing neighborhoods. A lot of our ARPs in existing neighborhoods, take the Oliver as an example, the ARP in Oliver is like 20 years old, so the plan is completely outdated. The template for redevelopment in the Oliver neighborhood isn't even applicable today to what you would actually want to build. We need to do a lot of work to create an environment where it's just easier to redevelop in mature neighborhoods once it's easier to redevelopment mature neighborhoods I think you'll find more dollars go into those neighborhoods." - Ryan Smith (Beaverbrook)

Andrew McLellan acknowledged that the ARPs can potentially be a barrier to development, specifically in regards to community consultation, but believes it is unlikely to be a significant one when addressing the type of major TOD projects examined in this research as the City is typically willing to amend the ARPs, and other statutory plans, as needed.

"The ARPs, most of them are pretty old, they're not aligned with the policy, they're not aligned well with what we more contemporarily want to actually see, especially with TOD because they were built at a time when that wasn't even a concept that people were even aware of. Now, how much of a barrier are they? Formally, they are the statutory plan, but when we get these kinds of situations we don't treat them like gospel. It's very common to amend them based on best practices, professional planning advice, the TOD guidelines. It's a hurdle, but it's not something that's going to be very hard to overcome. It might look like it at first, but we don't treat them as super strong, but then sometimes that upsets people in the community that were involved in making it plans years ago. So obviously we get into those kinds of difficult conversations in front of Council where people from the public want their plan to be maintained and a developer, and in a lot of cases the City, are saying, 'Yeah, the plan says that, but we don't actually think that's the right thing to do anymore."”

The TOD Guidelines provide some necessary guidance at important locations at various stages through the development application process, however, developers indifference to the policy aligns with public sector participants skepticism of the policy's efficacy. Developers also identified ARPs as potentially being a hindrance to development for their projects, and would like to see updated ARPs in area where there is TOD potential, and while the planner 
interviewed acknowledge may be an impediment, they generally believed the approach taken regarding ARPs and other statutory plans when reviewing TOD applications was sufficiently flexible. The policy environment created appears to be susceptible to the failures of other North American cities, as the City of Edmonton is utilizing a more passive strategy in which new policies are optional guidelines and implemented in addition to existing policies, seemingly creating some uncertainty and misunderstanding for both the public and developers (Cervero, 1994; Belzer \& Poticha, 2009; Duncan, 2010; Lee and Sener, 2017; Schuetz et al., 2018).

\subsection{Social and Physical Site Conditions}

Questions relating to the social and physical site conditions were asked to determine the extent to which these factors affect developers' investment decisions and the City's role in establishing the necessary preconditions for effective TOD according to the framework outlined in the methodology. More specifically, these questions were related to the desirability of the neighborhood in which project is taking place, integration of the transit station into the development, and the quality of the surrounding public realm, and the level of public investment in the site and station area.

Mixed opinion on the relevance of social condition to investment decisions was found amongst developers. Those in notably affluent or derelict neighborhoods stated that social conditions were important factors.

"It's the foremost reason for buying the land. We would not have bought a project like that. I would argue that there's maybe three neighborhoods in the entire city of Edmonton where we wouldhave invested dollars in a project like that is one of them. So first and foremost, location, location, location is always your number one factor in deciding what you're going to be, what you're going to undertake her build out for development. We saw Glenora as an area ripe for redevelopment because it's such a desirable neighborhood and they were missing a lot of the amenities that take a community to the next level."

- Ryan Smith (Beaverbrook) 
"It's one of the biggest factors in terms of getting people to buy into this area knowing that it can have some transient people flowing through. So it certainly impacts the design and definitely impacts in terms of the price in terms of what we were willing to pay for the land as well as selling some of the lots to the vertical guys. You're kind of pioneering the area, pioneering for infill in the sense that it doesn't have the best reputation and you've got to kind of prove to people that this will be a good place and it will be safe" - Warren Ollis (Brookfield)

Alternatively, developers with projects in middle income neighborhoods said social conditions were considered, but the importance was not emphasized to the same extent. One developer stated that with large projects even poor social conditions would not deter them and that they believe they can have a positive impact on a derelict neighborhood.

"That does make a difference, but generally our first approach is to see where there is population generally having decline." - Raj Dhunna (Regency)

"Yes, we did some studies in terms of discretionary income, what was necessary to really create a successful redevelopment of that site. So, absolutely. We looked at the various conditions in the area" - Representative of Nearctic and Rockwell

"We considered them, but we don't look at these things like we're looking at these redevelopments in today's world. In our mind, we're changing the environment, we're changing the feel. We have some pretty good living examples of places where we've introduced a significant residential and a commercial property and the crime in the area has actually gone down. We've got a site in Calgary at Brentwood Village that was adjacent to a park. And the park was known for some fairly unsavory things going on, in particular at night in there - pretty heavy drug use and stuff like that. We've now got two buildings that faced that park. That park has gone from a very unsafe place to one of the better parks in Calgary" - Stuart Craig (RioCan)

Physical conditions of the site and station area, and the extent to which there was public investment in these aspects of the site was also inquired about. Some developers discussed making an effort to integrate the transit station into their site, and in other cases, they were 
unconcerned, often because the station was adjacent to their site rather than part of it. The latter was the case Mill Woods (RioCan), Jasper Gates (RioCan), and Strathern (Nearctic and Rockwell).

"We turned our public spaces onto the LRT and we integrated the platform into the project and took the initiative to plan for the integration of the LRT. And I think right off the bat because of that the city really embraced what we were doing with it because some previous projects along the LRT line had done the opposite of that...But from property line in, property line out ours is $100 \%$ us and theirs is $100 \%$ them. We are funding it entirely out of our pockets. " - Ryan Smith (Beaverbrook)

"[The City] took a swath of land from us on the frontage to accommodate the actual station platform, and so their design of the platform was up for discussion. Although we're not completely enamored with the product that we've seen to date. We want to enhance that. Obviously, they had a certain budget to work within, but from our perspective it could have been more from a design perspective. They've got landscaping and they've got a multiuse paths which we're very happy with because we're going to be completely integrated with that. Like public realm was a big aspect of our development and integrating not only just the train but pedestrian flow on and off the site and a bicycle flow on the site." - Calvin McCourt (RioCan)

"At this point there is no agreement for any money into our private site. It's all private investments. It's happened in the past where the city has invested in turn I tried feel provided pretty good return on those kinds of things. But yeah, on this site specifically we have, we have a lot of publicly accessible amenities on private land." - Raj Dhunna (Regency).

Only one developer discussed public-private investment coordination, and this site is in a neighbourhood with poor social conditions and the station is one of the original Capital Line stations, all of which have struggled to attract TOD investment for myriad reasons including poor social conditions and transit integration. This was also the only developer who spoke of public-private investment coordination regarding the site itself and the station area, as plans to rebuild the transit station to better serve the site and improve integration have been proposed. It 
is important to note that the project is not part of the Quarters redevelopment area, as the developer states, although it was given access to funding from the Quarters tax increment financing system, which known as the community revitalization levy (CRL).

"I know our project wouldn't be viable without the cost share agreement with the city. It's just you can't make the numbers work by any means. I think that there are quite a few agreements like that. We had access to the CRL funding, because we're kind of in the Quarters district, so there's a big heavy push to get that going. You need the city involved. You need the city to be helping with some of those costs because it can benefit more than just that site and the city is going to get the tax dollars ultimately on the tax lift." - Warren Ollis (Brookfield)

"There was actually even a point where the city was looking at some concept plans for the LRT station that's existing there, and seeing if we can tweak our design a little bit for what the ultimate redevelopment of that station will be." - Warren Ollis (Brookfield)

However, Andrew McLellan believes the City could be contributing more to minimize the infrastructure upgrade costs to help mitigate risks and incentivize development. McLellan is also quoted on page 22, in which he says he believe in some instances there has been "an over assumption that transit is the only factor that's needed to spur development."

"We're still relying very much on private developers to take it on and take on a huge majority of the risk and the cost. For example, we don't preemptively go into these areas and upgrade infrastructure at the city's cost to try and encourage development. We still rely on a developer coming in and if they want to put a tower where there's no capacity in the pipes and the drainage and all that for a tower, then the cost is entirely theirs to upgrade. So in that sense it's almost creating more barriers, as opposed to really trying to incentivize it." - Andrew McLellan (Urban Planner)

Generally, station area integration seems to only be a concern to developers when the station is on their site rather than adjacent to it, and in these instances developers are choosing to invest in integration themselves. Public investment in the Muttart District site and station 
demonstrate the City's willingness to invest in instances where it is necessary improve the viability of the site. Both these examples demonstrate an understanding of the importance of investing in a site so it can support high density development, has access to transit, and is market viable (Cervero \& Seskin, 1995; Levine and Inam, 2004; Schuetz. et al., 2018; Fleissig \& Carlton, 2009; Lavery \& Kanaroglou, 2012; Utter, 2009; Guthrie \& Fan, 2016; Rene et al., 2016). Social conditions do seem to be a factor in these decisions as well, as demonstrated by developers' responses and the fact that the only site at which there was public investment was where the social conditions would have made development otherwise infeasible (Cervero \& Kockelman, 1997; Wood, 2009; Belzer \& Poticha, 2009). However, comments from planners suggest that the City is taking a passive approach toward TOD in regards to infrastructure, which, again, is a strategy that has being unsuccessful elsewhere (Cervero, 1994; Belzer \& Poticha, 2009; Duncan, 2010; Lee and Sener, 2017; Schuetz et al., 2018; Utter, 2009; Duncan, 2010; Guthrie \& Fan, 2016; James, 2009; Wood, 2009).

\subsection{Market Conditions}

Participants were also asked about how they perceived the market for TOD in Edmonton. Questions were premised on established literature indicating that positive population and economic growth and housing demand are necessary preconditions for TOD, as TOD redistributes existing demand from the urban periphery to higher density nodes (Cervero, 1984; Cervero \& Seskin, 1995; Higgins et al, 2014). Edmonton satisfies the criteria of population growth as the city often has exceptionally high population growth for a large city, and it experienced 14.8\% growth between 2011 and 2016, the highest of all large cities in Canada (Statistics Canada, 2017). Economic growth is currently strong in Edmonton, unemployment is 
high but falling, and labour force participation rate $7.6 \%$ higher than the national rate (Statistics Canada, 2018; Conference Board of Canada). This is reflected in the housing market as housing starts are also consistently high and vacancy rates are falling (Canadian Mortgage and Housing Corporation, March 2017; Canadian Mortgage and Housing Corporation, July 2017; Canadian Mortgage and Housing Corporation, July 2017).

However, these factors are complicated by the historically strong consumer preference for single family housing and suburban lifestyles, as much of the city's recent population growth is located in the periphery with many centrally located neighborhoods experiencing population decline (Lowe \& Lowe, 2018; City of Edmonton, n.d.). Given historical patterns, and that the city is surrounded mostly by farmland, outward expansions seems likely to continue unabated (Lowe \& Lowe, 2018; City of Edmonton, n.d.). Tendency toward overbuilding in recent years is likely exacerbated by these factors, and coupled with the abundance of opportunities for large TOD projects and intensification more broadly, circumstances seem likely to hinder effective build out of TOD sites (Housing Market Assessment: Edmonton CMA, 2019; Housing Market Assessment: Edmonton CMA, 2018). Further compounding this is the fact that high-density development in Edmonton is not as profitable as it is in many other cities. A confluence of factors that should be, and is, concerning to the TOD Manager.

"You look at the old municipal airport site, the exhibition lands... all of the available spaces that are in our market right now that are vacant... where are these people are going to come from that are going to move into these areas? How does that play into supply and demand and our visions and hopes and dreams for denser urban form? If we had nowhere else in the city to build and you wanted to be an urban dweller, Blatchford would fill up pretty quick if that was the only place that was available. But it's not." - Guy Boston (TOD Manager) 
"I've tried to understand who are these people that are coming to Edmonton and what are they looking for when they come here $-85 \%$ of the people that are coming here are looking for the suburb experience. Wherever they're coming from. If they're coming from Toronto because they can't afford a million dollar condo, they're gonna go buy a $\$ 500,000$ house in the suburbs and get to work in half the time it took them in Toronto. That's what they want. If you're coming from another country, a multi downtown is going to cost you a fortune but a multi in the 'burbs will be half of that. We just annexed a whole bunch of land again and we can accommodate a million people out there. The Edmonton Metro Region Board has their density targets, we can hit the $45 \mathrm{du}$ (dwelling units per hectare) with what we've got for vacant land and what we just annexed. So that's the challenge." - Guy Boston (TOD Manager)

"Investors want to see guaranteed returns and they're not going to lend you a dime until you've got 80 percent pre-sold or something, which is never going to happen in our market.” - Guy Boston (TOD Manager)

Four developers did not share these concerns, while Beaverbrook did and Brookfield had a mixed view. Larger developers emphasized the extended time horizons they operate on and were comfortable extending the build out of their project and waiting for more favourable market conditions. Some Alberta-based developers were confident that shifting generational lifestyle preferences would provide demand.

"I think with any of these projects you can't look at them and in today's terms because the approval process with them and subsequent construction can take years. You've got to look at them over a long term. Millwoods and Jasper Gates, for example, from our perspective are probably 20 year projects between when we started, when we finished, each phase is probably five years. By the time you get approval, you take two and a half years to build a kind of larger mixed use residential building and then you want to lease it up and make sure it's full before you move onto the next phase. In our mind, Jasper Gates, it's probably about a four phase project. Mill Woods might even be more than that with its size. It's easily 20 to 25 years. No one can sit here today and see what the market is going to be like 25 years from now. I think you plan for good planning and you let the market catch up if it needs to... Just hold off on a phase until we're comfortable that the absorption rate is appropriate. You do your zoning use on the entire site first and then you move forward with the individual phases of the development as the market demands."

- Stuart Craig (RioCan) 
"We're very happy that our investors are very much looking towards the future and is encouraging this kind of development moving forward and to be very integrative and be sustainable and something that they can be proud of for years to come because from an investment perspective they're hanging onto this for a long, long, long time and they're not just in it to make money and get out." - Calvin McCourt (RioCan)

"Anything that's coming on the market is going to affect the market. That being said, we believe that we've got a unique property. And if execute reasonably well I think that we can compete with just about anything out there" - Representative of Nearctic and Rockwell

"I think the new buyers of millennials and such are more geared to condo living rentals and stuff like that. And they're going to be a more attracted to inner city, easy transportation, stuff like that than they are the suburbs where you certainly most likely need a car or taking public transit can be a little more challenging." - Warren Ollis (Brookfield)

“Old neighborhoods haven't seen anything new being built in a long time, which speaks to the changing baby boomer demographic. Not all of them want to move downtown into a fancy tower, but they want to stay in the neighborhood they've been for 20 years. You're starting to see that shift. It started to occur about five years ago in Edmonton. That downsizing market has never really existed, but that's also because they didn't want to move out of the neighborhood and there was no opportunities for them. What you start to see is some of the older demographics, some of the seniors and baby boomers move out of the homes that they've occupied so long." - Raj Dhunna (Regency)

Ryan Smith from Edmonton-based developer Beaverbrook explained the incentives at play in Edmonton residents' housing decisions, seemingly reiterating concerns expressed by the TOD Manager, and stated that "its difficult to bring product at price points that are competitive with the suburbs."

"The reality is I can still buy a bungalow one neighborhood out of the downtown core for less than I can buy a condo. They're still attainable to a teacher and a firefighter or just two people with normal decent paying jobs. They can still live in desirable neighborhoods. If you go to Toronto, you've got to commute 2 hours before you can buy anything, and so you start to make tradeoffs, looking at alternative housing typologies, 
alternative ways of living, reducing to one car. There's all kinds of things you start looking at when you literally can't afford to have something. But in Edmonton, when you can still afford to have something, you don't have to make those decisions. And when you don't have to make those decisions, you don't make those decisions." - Ryan Smith (Beaverbrook)

Two Alberta-based developers and one Toronto-based developer also confirmed concerns about timely build out or stagnation of TOD sites due to the multiplicity of sites available, which is a phenomenon described in the literature (Utter, 2009; James, 2009; Higgins et al., 2014; Duncan, 2010).

"The problem is with that there is a problem when you start to create too many areas for redevelopment, you can curb the ability to gain momentum in any single area. And I think if you want to see some more traction in some of these mature areas focusing on building momentum in one area may have a better impact than trying to redevelop like six major areas at a time. It starts to get tricky if the city brings in Rossdale and the Quarters and Northlands all at one time. I think those just start to cannibalize one another and, and I don't think you'll see any kind of significant progress on any of them. You can't do everything at once." - Ryan Smith (Beaverbrook)

"I mean, it's great that we have all these sites that the city wants to push them along and get development going in these areas. That's all well and good, but at the end of the day if the market's not there developers will just slow down their production." - Warren Ollis (Brookfield)

Morguard, the Toronto-based developer who shared this concern, provided some insight

based on their experiences in Calgary:

"We have a property in Calgary too that seems to have the same kinds of issues where there are lots of pressures from low density developers wanting to have track line on the outside to make it affordable for people to buy single family homes. Calgary is having the same issue and it's even worse there because they built all the transit and they kept allowing sprawl to happen. They put the transit in, but no one's putting intensification on the transit. That's been an experience that I've seen recently and they're like, 'Oh man, we gotta do something about this. We can't have this keep happening.' So they started to throttle back and said they can only have so much growth in that outer node. Obviously, 
the developers are pounding the table saying 'Come on! This is what I do!' They pressure politicians to continue to allow sprawl to continue and I think that's going to be a fundamental mistake if you want to realize on your TOD site. You're going to have to say there is the limit. That's it. And now we need to start looking inward. Trains change the way you develop." - Calvin McCourt (Morguard)

Both Beaverbrook and Brookfield are Alberta-based developers that focus primarily on greenfield development, which was reflected in their comments as Beaverbrook rejected the notion that Edmonton is sprawling and Brookfield expressed concern about increasing off-site levies and the policies implemented in Calgary discussed above. Morguard, similarly, would benefit from a land use policy that limits greenfield developed as it specializes in large redevelopment projects. Developers' comments reflecting their business interests is not a problem, but it is important context that should be acknowledged in attempting to resolve the discrepancy between Edmonton's land use trajectory and its ambitions.

Economic conditions in Edmonton are conducive to TOD, but the culture and policies that shape that housing market are not as they do not aid the redistributive potential of TOD, allow the continuation of sprawl, and make Edmonton's TOD plans vulnerable to some of the same issues that have plagued similar cities (Guthrie and Fan, 2016; Hurst and West, 2014; Leach, 2004; Cervero, 1984; Cervero \& Seskin, 1995; Higgins et al, 2014). While this is a common and significant challenge, the TOD Manager understood the scope and nature of these issues and discussed his desire to better understand the potential to address the the possibility of site stagnation raised by three developers'.

\subsection{The Blatchford Redevelopment and Municipal Development Corporations}

Two of the most significant TOD sites in Edmonton are Blatchford and what is known as the Exhibition Lands. Neither is included in this research because of the exceptional amount of 
public sector involvement. A former airport, Blatchford is now a 217 hectare site being managed and developed by the City of Edmonton. The City has a detailed master plan, is servicing the land, creating a geothermal utility for the area, and seeking proposals from home builders for the parcels. The Exhibition Lands redevelopment is in preliminary stages, but there is potential for a similar model to be used. Questions about the multiplicity of large TOD sites and their impact on the market inquired about participants' opinions on the approach the City has taken at Blatchford, and subsequently about the potential for a municipal development corporation as municipal development corporations have been used successfully in many places for development generally and TOD specifically (Cevero \& Murakami, 2009; Utter, 2009; James, 2009; Guthrie \& Fan, 2016; Ratner \& Goetz, 2012; Curtis, 2008; Tan et al., 2014; Geen, 2016).

The TOD Manager said that there has been discussions within municipal administration and on council regarding the potential for a municipal development corporation, as the City currently owns and develops some industrial land on the periphery of the city in addition to Blatchford. Such an entity was proposed in 2015 by the expert panel formed to the study the issue based on successful examples such as the Calgary Municipal Land Corporation and Toronto Port Lands Company (CBC News, 2015). Local developers strongly opposed the proposal, although a Toronto-based developer was in favor, and it was abandoned (CBC News, 2015). Opposition would again be strong, if not moreso, as local developers' responses ranged from skeptical to hostile with some stating it would negatively impact their business and others mentioning their distaste for the approach taken in Blatchford multiple times unprompted.

"I don't think the city should be a for-profit land developer. There's just a little too much bureaucracy internally there that they can adapt and as much as developers can to the market. I think that the city, if they're going to be developing, like say a site like Blatchford is good if they're doing new innovative things which, they are Blatchford, that 
typical developers might not do because they're thinking more from a cost perspective, but the Blatchford where they're trying these new things, I think they are geothermal heating for houses and really great initiative. I think that's a great idea. I don't think that the city taxpayers should have to foot the bill if they start going over budget and stuff like that" - Warren Ollis (Brookfield)

"I think the city has a role to play if they want to see redevelopment on the larger scale, ensuring that land was put together to make that happen is one thing...Then taking an active participation in the development that I think is flawed... I think there is big visions for what Blatchford is going to be 30 years from now and I think there's a big disconnect between what it's going to be in 30 years and what it can be today and it's an area where I think they've made a number of mistakes in launching the project and not understanding what the reality of the market is today to achieve that vision. And so I think sticking to his very principled ideas is going to cause some issue to actually getting momentum and seeing this project move forward the way it would under typical private development scenario." - Ryan Smith (Beaverbrook)

"I'm not a fan of a city getting into the development business for obvious reasons. The advantages they may have create an unfair economic situation. Blatchford is an example of probably overreaching. It's a neat concept and theory, but when the time comes for private money, I'm not sure how many private businesses are going to jump on board...If you're the city and you're relying on private enterprise to be successful then you probably shouldn't be competing against it is my viewpoint. And they're talking about developing sites and the argument has been, 'Well, this is a neighborhood that private money wouldn't go into anyway.' Maybe that's the truth in some cases, but I believe some of the cases they're directly competing against the infill guys.” - Raj Dhunna (Regency)

"I don't think that's what they should be doing. I think the city definitely needs to have an overlay of it's guidelines because you do want to have certain principles to be followed by everybody. You want to create the conditions that are going to generate a great city. Beyond that, you might be getting too involved in it. It starts to create people working at cross purposes within the city administration." - Representative of Nearctic and Rockwell

Toronto-based developers were also somewhat skeptical of the approach being taken, although neither were particularly familiar with Blatchford. 
"Municipalities in my experience are not well equipped to take on role of developer. They really don't have the expertise in house to understand all of the intricacies involved in pulling a project together. Generally, municipalities can be useful in rezoning lands for sale or joint venture projects, but when it comes time to execute on the development they would be wise to partner with a seasoned development team. Otherwise they risk improper execution and financial leakage." - Calvin McCourt (RioCan)

"I know of some instances and other places where the city actually owned some land themselves and there's a line I think where they become not just the approval authority, but they also become a developer. And I think that's dangerous because I have a real problem with cities that give themselves a competitive edge if they own a piece of property over somebody who privately owned a piece of property. But I don't know really what the situations are with those properties you mentioned because I haven't been involved." - Stuart Craig (RioCan)

However, both developers as well as a local developer discussed other examples of municipal development corporations they were familiar with, what they preferred about them, and what they would like to see from a potential development corporation in Edmonton.

"I like [Calgary Municipal Land Corporation] because it's different. Yes, they were selling land but the city pumped a bunch of money into that area, like millions and millions of dollars to improve the infrastructure. Then they were selling land, but that land was being sold to generate tax base. They were selling the land at market value first of all, but that land was being sold and putting back into the city's tax base because they'd already upfront did millions of dollars to put these services and some of the amenities in the East Village that needed to be there to make it an attractive place to develop that. And that to me is different because they made the investment themselves first and then they were just recouping that money for the taxpayer. If it's a scenario where the city is not making the investment first and they're just acting like a developer and then benefiting down the road, I guess that's still helping the tax base, but I think it's a little less clear on how that money's being used in the CMLC case the money was funded by the city and then reimbursed through the process and it was very transparent." - Stuart Craig (RioCan)

"This idea is not a new one in Canada. Toronto has their Waterfront Toronto (all three tiers of government), there is Canada Lands Corp (federal), Ottawa has one and Calgary has one. Again they have people in house that are trained in visioning at a high level, but without the collaboration of the private developers they lack the knowledge of execution. 
It is one thing to have lofty ideals about what the art of the possible could be and quite another when you need to make financial sense of it all and remain on budget through the execution phase. I look at the example in Toronto for a chunk a land the City had owned called the Atarari lands. I was in university when these lands were under study by the City on what to do with them. It took the City decades to come up with a plan and then they opened it up to developers to execute on the lands...took a long time but ultimately was successful. So there definitely is a role that municipalities should take to dispose of their underutilized lands and leverage their assets wisely, but collaboration is key to get the best possible outcome." - Calvin McCourt (RioCan)

"I wouldn't mind the idea of the City having a separate development corporation if it was run separately similar to EPCOR (Edmonton Power Corporation). If it were to form, I would still like to see the focus on innovation, affordable housing and other initiatives private developers may shy away from. Also, other than initial funding from selling some currently City owned land holdings, there shouldn't be any tax dollars used or put at risk based on the performance and return of their projects. Basically, it should be self-sustaining similar to Canada Lands Corporation." - Warren Ollis (Brookfield)

The City is currently partaking in development to some extent and has expressed interest in forming a municipal development corporation previously and is being discussed again. There are many examples of successful municipal development corporations globally, including in Canada and Alberta. Many of these examples include TOD, in which a development corporation has been the entity through which the municipal demonstrates leadership and addresses many of the complex issues facing TOD (Cevero \& Murakami, 2009; Utter, 2009; James, 2009; Guthrie \& Fan, 2016; Ratner \& Goetz, 2012; Curtis, 2008; Tan et al., 2014; Geen, 2016). Currently, it would be difficult for the City to form such an entity, as previous fears about the development corporation directly competing with private developers have, in their eyes, been validated by the actions taken by the City at Blatchford. 


\subsection{TOD Manager and Municipal Administration}

Guy Boston was selected for the newly created TOD Manager position in August 2018.

Creation of a position to help facilitate development along the Valley Line specifically and more urban, efficient land use more broadly was suggested by one of the founding members of the TOD Institute of Canada to the Mayor and City Council. Substantial political support and administrative access has been given to Boston in the role.

"Because I am reporting through to the infrastructure department, and supported by the Mayor and City Manager and the executive leadership team in my role, I have unfettered access to and poke at absolutely everything and every department that is involved in supporting the development of this higher and denser urban form vision we have for the city." - Guy Boston (TOD Manager)

"I have people that want to join my team. I don't have a team yet, but you know, I have a number of branch managers that at a call will have a meeting. So I have the Manager of Planning and Development, Peter Olhm. Chris Hodgson is the manager of real estate, so he sits in with me. I've got the two managers of both Blatchford and exhibition lands that sit with me and then um, we have a Director of Urban Development and Mary Ann Dubrinsky is her name. She also sits on this committee that we have, we call it the city building team, but I mean those are basically the five or six people that, you know, literally have their fingers on the pulse of what's going on and are actually agents of or supporters of or in the processes of managing how we grow up our city." - Guy Boston (TOD Manager)

"So Municipal Development Plan/Transportation Master Plan, Kalen Anderson who's leading it up, she's, again, totally involved with what I'm doing. She's plugged into it, she sees what I'm undertaking is going to be a helpful feed into what ultimately will come to council in September as to the direction of MDP." - Guy Boston (TOD Manager)

According to Boston, he is currently determining what the role will entail and how it can be most effective, and he plans to hold a symposium and continue consulting with key stakeholders in both the private and public sector. Boston is planning on assessing the potential of creating a prioritization strategy for TOD areas to ensure build out of TOD sites and prevent stagnation - 
what he refers to as an "urban development strategy" - and also establishing the TOD Manager as someone who builds relationships with key stakeholders and assumes the role of facilitator ("concierge role") within administration when large TOD projects are proposed.

"Yeah, so imagine now that we have the urban development strategy developed and we have the priorities. I don't know if its prioritized by geography or prioritized by development size, but let's just say that's been established and that somebody is interested in doing something on it or we decide that one of the city investments is going to be the target, this concierge role would be to either attract the investors to that spot or to actually assist in any way, shape or form, to be the advocate for the developer in the city to help it advance.” - Guy Boston (TOD Manager)

"The city may undertake a concierge service or do something different around how we manage the whole application process for developers or investments that are aligned with the city's goals and visions." - Guy Boston (TOD Manager)

Both these ideas were discussed by developers. Importance of prioritizing development areas was mentioned by only one participant, but all developers stated that the most significant impediment to the advancement of their project was a lack of coordination or understanding within administration and between departments. With one developer suggesting they would not likely be willing to undertake such a project again and that the City will not be able to achieve its goals if this is not addressed.

"The biggest challenge that I think was that we did have some delays on the Mill Woods process. They were largely because we were waiting for different segments of the city to get aligned on the same page in terms of what their expectations were of us.... When we were going through our zoning process planning and transportation we're not aligned. Planners we're much more in tune with what we were trying to do. The transportation guys didn't seem to quite get that as much. Quite frankly, the planners and transportation guys got into, um, I would say some heated discussions during our approval process about these kinds of things." - Stuart Craig (RioCan)

"These projects are quite complicated and typically involve a lot of give and take to be able to pull them off and you run into lots of challenges with the City and dealing with 
multiple different departments and it's very hard to meet the technical requirements of all the different departments when you're stacking multiple uses in a more dense environment, especially when you're integrating vertically." - Ryan Smith (Beaverbrook)

"I would say that one of the big problems with the city is a lack of vision and understanding of the issues related to large scale infill development. Larger scale development, there's a lot of complicating factors to take into consideration. If the focus is on large scale developments you need a more comprehensive approach so that every different department doesn't hang up a large project... It's certainly delayed our ability to execute. It's taken a long time. As we've gone through a zoning discussions and applications and all the rest of it made it much lengthier and much more costly...I think that's largely due to the amount of turnover in the various departments, and a lack of senior leadership of in terms of dealing with large projects." - Representative of Nearctic and Rockwell

"You've got the billion dollar LRT running through. You've got to stop right in front of this site. And here we are spending a year and a half arguing that there should be density on this site. That's a concern I took so long to get the approvals here when it shouldn't have. For a guy like me, after the Holyrood experience, I'm not really interested in going through another rezoning to be honest. That's saying something given I've done eight or nine of these now. I'm not sure how my competition feels or other infill developers feel, but if it's not easier to get done then the success of some of this investment isn't going to come as quickly as people think." - Raj Dhunna (Regency)

One developers explained that the difficulty of the approval process is a result of municipal administration being unfamiliar with this type of development and primarily oriented toward low-density, auto-oriented development, which the planner reinforced.

"The biggest hurdle was getting our drawings approved through administration. A lot of the stuff that we were doing was not typical subdivision stuff. And we did get a lot of pushback from administration...doing some stuff that's not standard or typical that the city departments are generally don't want to go outside of their box a whole bunch."

- Warren Ollis (Brookfield)

"It's still very easy in Edmonton to do greenfield suburban growth. Everything about our process and our land development process and the city's process is like a machine that's 
really good at that, and not so much when it comes to the large infill stuff. It's still pretty much all on the developer and there's a lot more challenges to doing that. Probably, the city could do more to incentivize that kind of thing." - Andrew McLellan (Urban Planner)

All private sector participants also expressed some interest or a strong desire for the TOD

Manager to assume the role of facilitator within administration.

"You need them to become a champion of the project on the public side. Not somebody who's just here to to pump up the development industry, but somebody who when you bring a project forward they can look at it and go, 'Okay, I understand what you're doing, I get what you're doing.' and then become a bit of a champion on the other side." Ryan Smith (Beaverbrook)

"I think it's good that the city is being actively involved in it. Generally it'd be developers kind of coming up with what might be a good spot for TOD, but it's good that the city at least have somebody that can help facilitate that. This position might make somebody say go a little smoother with the developers have proposals or ideas for the areas." - Warren Ollis (Brookfield)

"There's a lot of nuances and I think special circumstances surrounding TOD, especially given that, in Edmonton, it's relatively in its infancy. There's a lot of stuff that goes on and a lot of things I think the city needs to understand from the community and developer point of view that they don't have knowledge today on. I think it's empowering your city employees to be able to provide clear cut answers. Empowering your representatives to say, 'Hey, you know what? Okay, you're looking for more expertise in this. Let me find you someone and get you more information.' When you're relying on planners of certain areas they're used to doing it a certain way. I think the TOD manager would help keep it on the pulse to say, 'Yes, that's how you've done it but in this case, here's what we learned."' - Raj Dhunna (Regency)

"I think the city should actually have somebody who's focused on large product and we've actually asked them to do this. So you would have somebody who's focused on larger projects and bringing into line all the various departments." - Representative of Nearctic and Rockwell

"I can't again speak to the history of Edmonton, but larger sites obviously need to be handled in a different way. These are not just like a half acre or one acre sites where 
you're just plunking a building or two. And so it needs more time and effort when handling it through a process, not only from a resource perspective at the city, but from how you present that project to the general public and then all the other repairs and all the other stakeholders at the table." - Calvin McCourt (Morguard)

"I think it's important to have some staff that understand the nuances of TOD. Although I will say I have no complaints with Edmonton staff, our file manager very much understood what we were trying to achieve. I think it doesn't hurt to have even more expertise in a position like that." - Stuart Craig (RioCan)

Planners have already established an element of such a process. Andrew McLellan is the main planner for Holyrood Gardens, Bonnie Doon Town Centre, and will be involved in Strathearn Heights upcoming zoning amendment. According to McLellan, a three stage process has been established and is being refined.

"With the large site TOD stuff, we've done a different approach because we want everything to be a bit more collaborative, understanding that the large sites can have significant impact...Typically, what we do is we kind of follow kind of a three stage approach where we get [the developer] to sort of share their vision and principles, high level stuff. We have some negotiations on that, we talk to some of the other people in different parts of the City to see what priorities might be within the City that we want to align with their project. And then, once we've kind of agreed on those pieces, we move into concept developments. And again, usually it's the developer that's leading, bringing a concept, and then this is a lot of review the city does and negotiation. A lot of times what we'll see is that a developer wants a lot of development rights and they don't really want to specify where on the site it is because it's large sites and they want to have the ultimate flexibility going forward, but from the city side we have an interest in the public good and need to look at what's just around the site. Like in Holyrood, there's a very low density neighborhood right next door, so there was a lot of negotiations to make sure that they're built form was appropriate in terms of compatibility with that lower density development nearby. We just did a lot of negotiations and we try and push back on things and then try and find a balance that works for the developer and for the city. And then the third and final stages is getting that design into actual zoning regulations and bylaws, which is more just the technical side, not so much the actual projects or design level." Andrew McLellan (Urban Planner) 
"We kind of have just started trialing it, so we did it a little bit like this with Holyrood, but Bonnie Doon was really the first one that we did that kind of approach with. There's definitely things we learned, and lessons learned from Bonnie Doon specifically. Bonnie Doon still hasn't been approved by council so we're still kind of finishing things off but the plan is to kind of have a debrief on that and come up with lessons learned. So that we can, for the next one, maybe for Strathearn Heights or there's other ones in the city as well we'll improve upon that, but we don't really have a comparison done yet."

- Andrew McLellan (Urban Planner)

This process is undertaken by a "review team" that is formed on an ad hoc basis. Team members from relevant municipal departments are included, but their work remains disconnected from the TOD Manager and it is "not an integrated team."

"Guy Boston is the Manager for TOD, but he works in a completely different group from where I work that deals with the actual hands on negotiations and rezoning with the developer. Within my area there's no specific group of people that would only deal with these. We just assign people as this type of application comes in based on experience and work load and obviously we will ensure that the people that get these big ones are kind of on the more experienced or more capable side of doing this kind of thing because they are such a complicated, complex project. One thing we've tried to do with the Bonnie Doon one is at the beginning we identify who all the city people that are going to be involved, no matter where they are in the city, and not formally, but we basically make a review team and they have meetings together to make sure everyone's on the same page and then try to function as one unit, even though formally they still work in various places in the city. So we recognize that it definitely could be an issue and probably has been and so we're trying to be more consistent in the future." - Andrew McLellan (Urban Planner)

To summarize the process outlined above by McLellan: stage 1) establish an informal interdepartmental 'review team', consult with relevant municipal departments, discuss high level design principles and vision with the developer; stage 2) developer led concept development and negotiations; stage 3) zoning bylaw amendment process. He also states that the purpose is to establish a more collaborative process that both the city and developer are involved early in the development process. This process represents the type of collaborative, 
facilitation role discussed by all developers and the TOD Manager and is an attempt to address the lack of understanding and coordination within municipal administration on large TOD projects that was identified by developers as the most significant hindrance to TOD and precipitating a shift in land use patterns. All developers expressed a desire for the City to take action to address this issue, and the establishment of 'review teams' and their process present an opportunity for the TOD Manager and municipal administration. 


\subsection{Summary of Findings}

\section{Transit Technology and Route Selection}

Decision to opt for low-floor seems to have had a somewhat positive or negligible effect on TOD investment at this stage. Two participants preferred the low-floor LRT specifically, two preferred it to BRT, and two were indifferent to the type of transit. Route selection was questioned by one local developer as they did not believe it would be easy to assemble land along the corridor. Two local developers questioned whether the construction sequencing of the transit expansion was ideal for TOD. However, all developers except for one benefited from positive social site conditions, which are a result of the route selection, and one developer stated they believe the Valley Line South (Phase 1) route is effective because it touches on large underutilized pieces of land at Holyrood Gardens, Strathearn Heights, and Bonnie Doone Town Centre.

\section{TOD Guidelines and Area Redevelopment Plans}

Developers seem to be largely indifferent to the TOD Guidelines, some stating they had little impact on their investment decisions, and both public sector participants questioned their efficacy, but acknowledged they can be useful at times and do provide guidance during negotiations. Local developers' also identified Area Redevelopment Plans as a hindrance. The ARP was seen as a hindrance to the Holyrood Gardens project specifically, and to TOD and development generally. Planner, Andrew McLellan, acknowledged that ARPs and other statutory plans could potentially be an impediment, but believed the approach taken to ARPs and other statutory plans when reviewing TOD applications was sufficiently flexible. The policy approach 
taken in Edmonton seems to be passive, which has shown to be ineffective in facilitating TOD elsewhere.

\section{Social and Physical Site Conditions}

Site conditions were clearly considered by developers as a factor in their investment decisions. Neighborhood affluence was identified as being the critical factor in deciding to invest the West Block site, and most developers projects were located in desirable, relatively affluent neighborhoods, although developers of these sites did not emphasis the importance of social conditions. One site was located in an area with poor social conditions and public investment was made in the physical conditions of the site to compensate for this and make the site viable. Other developers also indicated that they considered physical conditions, as those with transit stations located on site invested in station integration to improve their site. Only one site received public investment to make TOD viable on site, and the planner stated that more public investment infrastructure is needed to facilitate TOD in Edmonton.

\section{Market Conditions}

Developers do not perceive market conditions to be a factor that is hindering TOD, despite historically strong consumer preference for single family housing, more narrow profit margins for high density development than in other cities, and the abundance of large site development sites. This was due to the long time horizons that large developments operate on, at least on the part of large, Toronto-based developers, and due to the perception that shifting generational preferences will generate demand. However, three developers expressed some concern that the number of TOD sites and large redevelopment areas could lead to slow build out and stagnation of sites. Site stagnation as well as a lack of policies that redistribute growth from 
the periphery to TOD sites, is a problem identified in the literature and have plagued other cities in the past. Past urban experiences and developers' concerns provide more reason for the TOD Manager to move forward with their site prioritization strategy.

\section{The Blatchford Redevelopment and Municipal Development Corporations}

There was strong opposition amongst all developers who were aware of the Blatchford redevelopment to the City's approach taken there, and skepticism amongst those who were not familiar with Blatchford. This contributed to the skepticism and hostility expressed by most participants to a potential municipal development/land corporation. Organized opposition to creating a development corporation would likely be stronger than it was to a similar proposal in 2015. However, some developers were open to the idea on the basis that it functioned differently and said they would be open to a corporation that functioned similar to the Calgary Municipal Land Corporation, the Canada Lands Corporation, or Waterfront Toronto.

\section{TOD Manager and Municipal Administration}

The most important finding of this research is that all developers identified the lack of understanding and coordination within municipal administration throughout the approvals process as the most significant hindrance to TOD and precipitating a shift in land use patterns. All participants were open to or expressed desire for the TOD Manager to take action on this issue. Andrew McLellan explained that an informal process has been established to address this issue in which interdepartmental 'review teams' are formed which then proceed through a collaborative three stage process. This is an opportunity for greater collaboration between TOD Manager and planners who have established this process for both 
to acquire a better understanding of the TOD process and to potentially create a more formalized process. 


\subsection{Recommendations}

\section{Recommendation 1}

\section{Create a TOD Team.}

Developers expressed a strong need for a discrete entity within municipal administration that is responsible for managing and facilitating TOD projects and operates above and between relevant departments. I recommend that the TOD Manager form a team that includes staff from necessary departments and operates under the TOD Manager and can utilize the administrative access and connections afforded to that position.

\section{Recommendation 2}

Formalize the Review Team and major TOD application process.

The TOD Team should build on the work that has been done by planners working on major TOD applications and take on the role of the review team and formalize and continue to refine the three stage process that has been established. This would perform the 'concierge role' discussed by the TOD Manager.

\section{Recommendation 3}

Review TOD policies.

The TOD Guidelines are seen as ineffective and statutory plans, specifically ARPs, are seen as an impediment to development. The TOD Team should review and update the Guidelines and seek to better understand the extent to which statutory plans serve as an impediment to TOD, and if necessary identify key locations where statutory plan updates need to be undertaken to facilitate TOD, as was done on 104th Street. If ARP updates are not deemed necessary, creating a strategy for communicating the concept of TOD and relevant policies to developers and the 
public may mitigate the perception on ARPs as an impediment to development and the type of portracted public consultations seen at Holyrood Gardens.

\section{Recommendation 4}

\section{Create a TOD Strategy.}

The TOD Team should create a coherent TOD Strategy that aims to aid the potential of TOD to redistribute development from the urban periphery to transit nodes. Part of this needs to address the potential for site stagnation due to the abundance of large development opportunities identified by some developers in this research and in academic literature by creating a site prioritization strategy, or as it was referred to by the TOD Manager an 'urban development strategy'. Methods of incentivization should be explored such as infrastructure cost-sharing, as mentioned in the findings.

\section{Recommendation 5}

Consult developers about creating municipal development corporation.

The TOD Manager should, working in partnership with other relevant municipal departments, consult the development industry extensively about creating a municipal development or land corporation. The City of Edmonton is already involved in land development, and development and land corporations have been effective tools for facilitating large scale redevelopment and TOD in many cities. Creating such an entity would be worthwhile, but significant outreach and consultation with developers is needed to ensure the corporation is organized in a way that it can achieve municipal goals and does not generate strong private-sector opposition as it has previously. 


\subsection{Appendices}

\subsection{Appendix 1 - Terms of Reference}

City Plan: The name of the new Municipal Development Plan and Transportation Master Plan that are being developed in conjunction and are to be completed in 2020.

Edmonton Metro Region Board: A board composed of municipal government representative from the regional municipalities and counties that is responsible for creating a regional growth plan, infrastructure servicing plan, and an agricultural land management plan.

Statutory Plans in Alberta

- Municipal Development Plans (MDP) are city-wide plans that provide long-term direction for the development of an entire city.

- Transportation Master Plan (TMP) are city-wide plans that provide long-term direction for transportation in an entire city.

- Area Redevelopment Plans (ARP) are area-specific plans that guide the redevelopment of already built up areas.

- Area Structure Plans (ASP) are area-specific plans that guide the development of greenfield areas.

\subsection{Appendix 2 - Redevelopment Areas}

\section{Ice District}

Ice District is a multiphase mixed use development in downtown Edmonton. Phase 1 includes an NHL hockey stadium, 1 office tower, 3 mixed use towers, and a public plaza. This project was not included in this research because it included \$226 million dollars of public funding, part of which was provided through a tax increment financing system (City of Edmonton, n.d).

\section{The Quarters}

The Quarters is a 40-hectare redevelopment area adjacent to downtown Edmonton. The site is unique in that a significant amount of public funding, provided partially through an area-specific 
tax increment financing system, and there are a number of area-specific plans and policies in place. For these reasons is has not been included.

\section{Blatchford}

The Edmonton City Centre Airport closed in 2013 is now a 217-hectare redevelopment area known as Blatchford. A master plan was selected through an international design competition and the site is to house 30,000 residents when complete and include low-emissions geothermal energy. The City of Edmonton is servicing the land, building the utility, and managing the redevelopment. Due to nature of the project and the extent of public sector involvement it was not included in this research despite being considered a TOD site. Given that the site is to house 30,000 residents represents significant intensification (Perkins+Will, 2012; City of Edmonton, n.d.)

\section{Exhibition Lands}

The Exhibition Lands is a 81-hectare site that will be partially redeveloped. Currently, these lands are owned by the City of Edmonton and they have begun the preliminary planning stages. Given public ownership of the lands and the buildings on the land, it was not included in this project (City of Edmonton, n.d.) 


\section{Redevelopment Areas}
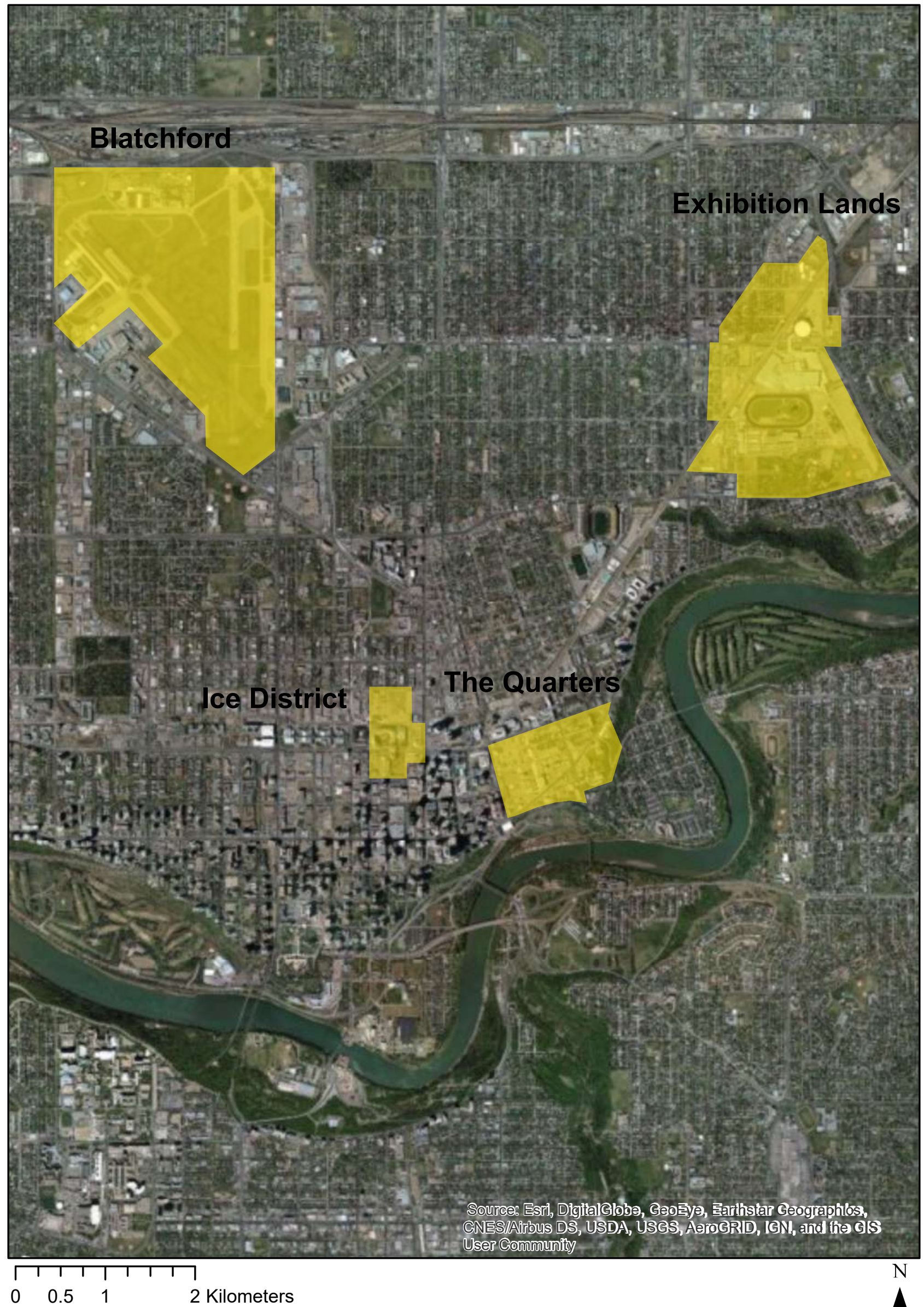


\section{Redevelopment Area Map Context}

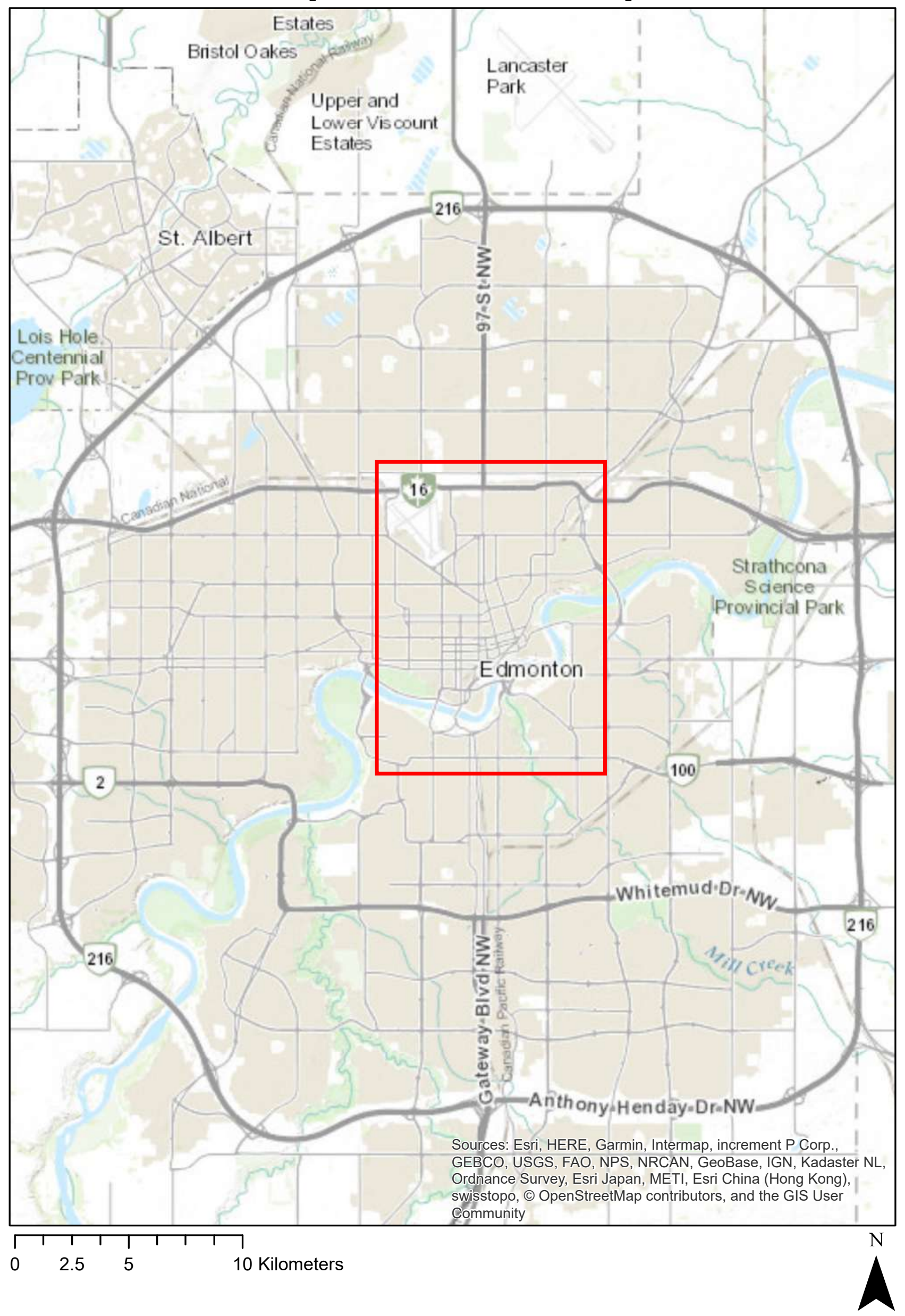




\subsection{Appendix 3 - Station Area Map and LRT Network Plan}

Figure 10: Station Area Types

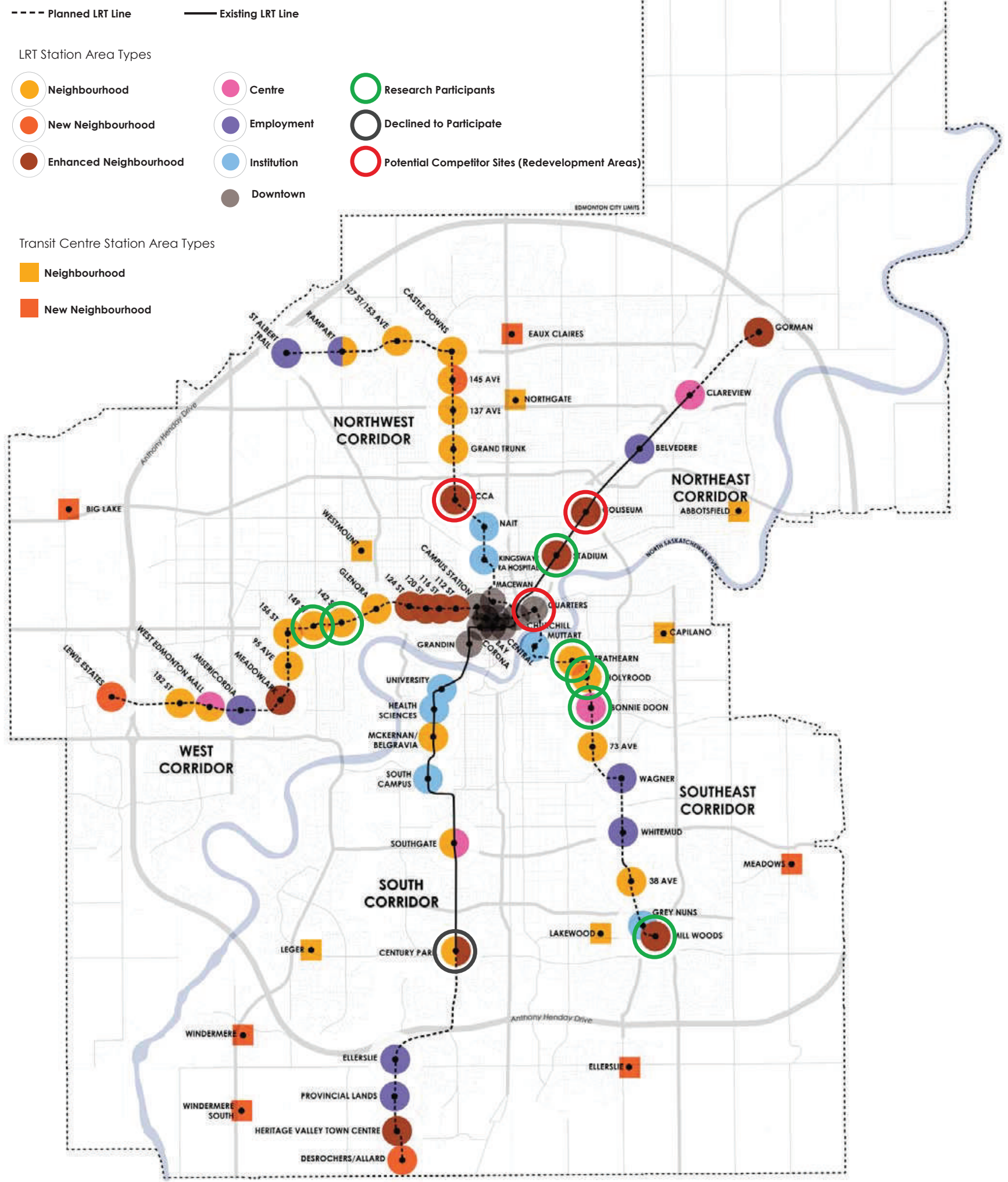




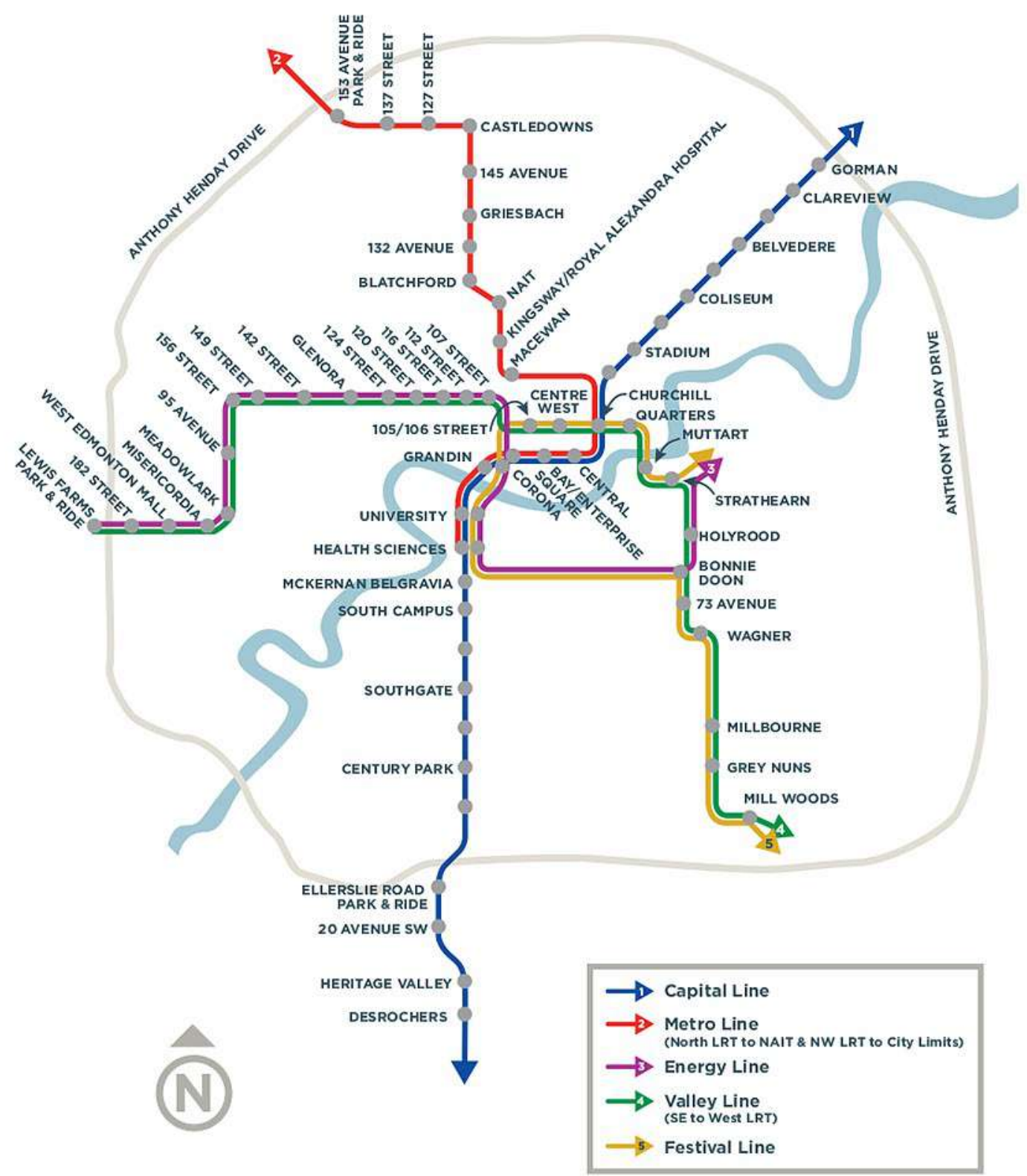

As Edmonton grows, our transportation needs are outpacing infrastructure capacity. LRT provides a proven, high-quality, high-capacity, efficient and environmentally-friendly means to move people.

In June 2009, City Council adopted a long-term LRT Network Plan that defines the future size, scale and style of the regional LRT system. Eventually, the LRT network will have six lines extending to the northwest, northeast, east, southeast, south, and west.

The LRT Network Plan supports City Council's overarching policy direction by making downtown Edmonton the focal point of the LRT system. In reviewing the overall system operation, it was determined that future expansions would need to operate on separate LRT lines.

As part of the LRT Network Plan, a review was completed to help choose the style of LRT service most appropriate to meet Edmonton's future needs. The review recommended a new, low-floor system of LRT for lines not directly connecting to the current LRT system.

The Valley Line will be part of this new system, and will both connect with other low-floor LRT lines, and offer an interchange withEdmonton's existing high-floor system. 


\subsection{References}

Arrington, G. (2003). Light Rail and the American City: State-of-the-Practice for Transit-Oriented Development. Retrieved from http://www3.drcog.org/documents/archive/lrt\%20and\%20tod.pdf

Belzer, D., \& Autler, G. (2002, June). Transit Oriented Development: Moving from Rhetoric to Reality (Rep.). Retrieved February 28, 2019, from The Brookings Institution Center on Urban and Metropolitan Policy \& The Great American Station Foundation website: https://www.brookings.edu/wp-content/uploads/2016/06/belzertod.pdf

Blair. C. C., (2009). The Public Sector Perspective. In Living Cities (Eds.), Fostering Equitable and Sustainable Transit-Oriented Development Briefing Papers for a Convening on Transit-Oriented Development (pp. 1-54). http://iri.hks.harvard.edu/files/iri/files/fostering-equitable-and-sustainable-transit-oriented -development.pdf

CBC News. (2015, November 27). Council accused of conflict of interest in profit-making development plan. CBC News. Retrieved February 21, 2019, from https://www.cbc.ca/news/canada/edmonton/industry-denounces-city-s-profit-making-dev elopment-plan-1.3339311

Canada Mortgage and Housing Corporation. (2017, March). Single Housing Starts: Canada, Provinces and Metropolitan Areas. Retrieved March 15, 2019, from Canada Mortgage and Housing Corporation website: https://www.cmhc-schl.gc.ca/en/data-and-research/data-tables/single-housing-starts-cana da-provinces-metropolitan-areas

Canada Mortgage and Housing Corporation. (2017, July). Housing Market Indicators: Canada (Rep.). Retrieved March 15, 2019, from Canada Mortgage and Housing Corporation website: https://www.cmhc-schl.gc.ca/en/data-and-research/data-tables/housing-market-indicators

Canada Mortgage and Housing Corporation. (2017, July). Housing Market Indicators: Edmonton (Rep.). Retrieved March 15, 2019, from Canada Mortgage and Housing Corporation website: https://www.cmhc-schl.gc.ca/en/data-and-research/data-tables/housing-market-indicators

Cervero, R. (1984). Journal Report: Light Rail Transit and Urban Development. Journal of the American Planning Association, 50(2), 133-147. doi:10.1080/01944368408977170 
Cervero, R. (1994). Transit-based housing in California: Evidence on ridership impacts.

Transport Policy, 1(3), 174-183. doi:10.1016/0967-070x(94)90013-2

Cervero, R., and S. Seskin. (1995). An evaluation of the relationships between transit and urban form. Research Results Digest. Washington, DC: Transportation Research Board.

Cervero, R., \& Kockelman, K. (1997). Travel demand and the 3Ds: Density, diversity, and design. Transportation Research Part D: Transport and Environment, 2(3), 199-219. doi:10.1016/s1361-9209(97)00009-6

Cervero, R. (2004). Transit-oriented development in the United States: Experiences, Challenges, and Prospects. Washington: Transportation Research Board.

Cervero, R., \& Murakami, J. (2009). Rail and Property Development in Hong Kong: Experiences and Extensions. Urban Studies, 46(10), 2019-2043. doi:10.1177/0042098009339431

Cervero, R., \& Dai, D. (2014). BRT TOD: Leveraging transit oriented development with bus rapid transit investments. Transport Policy, 36, 127-138.

doi:10.1016/j.tranpol.2014.08.001

City of Edmonton. (n.d.). People Population Change by Census Tract, 2006-2016. Retrieved March 26, 2019, from https://www.edmonton.ca/city government/documents/PDF/People Population-Change. pdf

City of Edmonton. (n.d.). History of ETS. Retrieved January 18, 2019, from https://www.edmonton.ca/ets/ets-history-statistics.aspx

City of Edmonton. (2009, May). Vehicle Technology Review: Fact Sheet (Tech.). Retrieved March 1, 2019, from City of Edmonton website: https:/www.edmonton.ca/documents/VehicleTechnologyReviewFaceSheetMay2009.pdf

City of Edmonton. (2012, March). Long-term LRT Expansion: LRT Network Plan [Press release]. Retrieved January 15, 2019, from https://www.edmonton.ca/documents/PDF/Long_Term_LRT_Network_Plan_March_201 $\underline{\text { 2.pdf }}$

City of Edmonton. (n.d.). The Agreement. Retrieved March 18, 2019, from https://www.edmonton.ca/attractions events/rogers place/the-agreement.asp

City of Edmonton. (n.d.). Welcome to Blatchford. Retrieved March 18, 2019, from https://www.edmonton.ca/projects_plans/blatchford.aspx 
City of Edmonton. (n.d.). Edmonton Exhibition Lands. Retrieved March 18, 2019, from https://www.edmonton.ca/projects_plans/edmonton-exhibition-lands.aspx

Conference Board of Canada. (2017, Autumn). Metropolitan Outlook 1.0: Economic Insights Into 13 Canadian Metropolitan Economies. Retrieved November 9, 2018, from http://www.pubmanitoba.ca/v1/proceedings-decisions/appl-current/pubs/2017 mh gra/irs to interveners/coalition-cow il-attachement1.pdf

Crowther, S. (2017, November 12). Rebooting Century Park. Retrieved February 20, 2019, from https://www.theglobeandmail.com/real-estate/calgary-and-edmonton/edmontons-centurypark-gets-a-long-awaitedreboot/article33347548/

Duncan, M. (2010). The Impact of Transit-oriented Development on Housing Prices in San Diego, CA. Urban Studies, 48(1), 101-127. doi:10.1177/0042098009359958

Fleissig, W. K. \& Carlton I. R. (2009) The Investment/Finance Perspective. In Living Cities (Eds.), Fostering Equitable and Sustainable Transit-Oriented Development Briefing Papers for a Convening on Transit-Oriented Development (pp. 1-54). http://iri.hks.harvard.edu/files/iri/files/fostering-equitable-and-sustainable-transit-oriented -development.pdf

Goyette, Linda, and Caroline Jakeway Roemmich. Edmonton: In Our Own Words. University of Alberta Press, 2004

Green, J. (2016). The Development Corporation Model's Impact on Municipal Planning Policy, Development Process and Standards: The Calgary Municipal Land Corporation (Unpublished master's thesis). University of Manitoba. Retrieved March 26, 2019, from https://mspace.lib.umanitoba.ca/xmlui/bitstream/handle/1993/32101/geen_jillian.pdf?seq uence $=1 \&$ is Allowed $=y$

Hess, D., \& Lombardi, P. (2004). Policy Support for and Barriers to Transit-Oriented Development in the Inner City: Literature Review. Transportation Research Record: Journal of the Transportation Research Board, 1887, 26-33. doi:10.3141/1887-04

Higgins, Christopher, et al. 2014. Light Rail and Land Use Change: Rail Transit's Role in Reshaping and Revitalizing Cities. Journal of Public Transportation, 17 (2): 93-112. DOI: http://doi.org/10.5038/2375-0901.17.2.5 Available at: https://scholarcommons.usf.edu/jpt/vol17/iss2/5 
Holtzclaw et al. (2002). Location Efficiency: Neighborhood and Socio-economic Characteristics Determine Auto Ownership and Use - Studies in Chicago, Los Angeles, and San Francisco. Transportation Planning and Technology, Vol. 25, pp. 1-27

Housing Market Assessment: Edmonton CMA (Rep.). (2018, February/March). Retrieved March 19, 2019, from https://www.cmhc-schl.gc.ca/en/data-and-research/publications-and-reports/housing-mar ket-assessment

Housing Market Assessment: Edmonton CMA (Rep.). (2019, January/February). Retrieved March 19, 2019, from Canada Mortgage and Housing Corporation website: https://www.cmhc-schl.gc.ca/en/data-and-research/publications-and-reports/housing-mar $\underline{\text { ket-assessment }}$

James, B. (1999). The Property Sector as an Advocate for TOD. In C. Curtis, J. Rene \& L. Bertolini (Eds.), Transit Oriented Development: Making it Happen (pp. 187-200). Surrey: Ashgate Publishing Limited.

Jones, E. (2006), Presentation given to Wynnum Enquiry by Design. In James, B. (1999). The Property Sector as an Advocate for TOD. In C. Curtis, J. Rene \& L. Bertolini (Eds.), Transit Oriented Development: Making it Happen (pp. 187-200). Surrey: Ashgate Publishing Limited.

Kent, G. (2017, May 09). Long-awaited Glenora condo project half sold, developer says. Retrieved February 20, 2019, from https://edmontonsun.com/2017/05/08/long-awaited-glenora-condo-project-half-sold-deve loper-says/wcm/8da09255-2d89-4cb7-ac2b-c1b319831ff9

Knight, R., \& Trygg, L. (1977). Land use impacts of rapid transit: Implications of recent experience. doi:10.2172/5952387

Lavery, T., \& Kanaroglou, P. (2012). Rediscovering Light Rail: Assessing The Potential Impacts of a Light Rail Transit Line on Transit-Oriented Development and Transit Ridership. Transportation Letters, 4(4), 211-226. doi:10.3328/t1.2012.04.04.211-226

Levine, J. (2012). Zoned Out Regulation, Markets, and Choices in Transportation and Metropolitan Land Use. Hoboken: Earthscan.

Levinson, H., Zimmerman, S., Clinger, J., Rutherford, C. (2002) Bus Rapid Transit, vol. 1: Case Studies in Bus Rapid Transit, Transit Cooperative Research Program, TCRP Report 90, Washington, D.C. 
Lightbody, James. City Politics, Canada. Broadview Press, 2006.

Lowe, S., \& Lowe, S. (2018, June). Edmonton's Urban Neighbourhood Evolution (Rep.).

Retrieved March 25, 2019, from City of Edmonton website: https://www.cityofedmontoninfill.ca/public/download/documents/46666

Mathur, S., \& Ferrell, C. (2013). Measuring the impact of sub-urban transit-oriented developments on single-family home values. Transportation Research Part A: Policy and Practice, 47, 42-55. doi:10.1016/j.tra.2012.10.014

Neuman, W. L., \& Robson, K. (2018). Basics of social research: Qualitative and quantitative approaches. Don Mills, Ontario: Pearson Canada.

Noland, R. B., Weiner, M. D., Dipetrillo, S., \& Kay, A. I. (2017). Attitudes towards transit-oriented development: Resident experiences and professional perspectives. Journal of Transport Geography, 60, 130-140. doi:10.1016/j.jtrangeo.2017.02.015

OECD (Organization for Economic Co-operation and Development). (2016, October 13). Cities will become inequality traps without better housing, transport policies. Retrieved April 10,2018 , from http://www.oecd.org/newsroom/cities-will-become-inequality-traps-without-better-housi ng-transport-policies.htm

Perkins+Will. (2012, May). City Centre Area Redevelopment Plan (Rep.). Retrieved March 18, 2019, from City of Edmonton website:

https://www.edmonton.ca/documents/plans in effect/City_Centre_ARP Consolidation.p df

Querengesser, T. (2018, April 20). Edmonton tries a new tack to spur development along LRT. Retrieved February 20, 2019, from https://www.theglobeandmail.com/real-estate/calgary-and-edmonton/article-edmonton-tri es-a-new-tack-to-spur-development-along-lrt/

Ratner, K. A., \& Goetz, A. R. (2013). The reshaping of land use and urban form in Denver through transit-oriented development. Cities, 30, 31-46. doi:10.1016/j.cities.2012.08.007

Residential Infill Guidelines (Rep.). (2009, September). Retrieved March 1, 2019, from City of Edmonton website: https://www.edmonton.ca/city_government/documents/PDF/Residential_Infill_Guideline s_Sept_2009.pdf

Rene et al., (2016). The Cost and Affordability Paradox of Transit-Oriented Development: A Comparison of Housing and Transportation Costs Across Transit-Oriented Development, Hybrid and Transit-Adjacent Development Station Typologies. Housing Policy Debate, 2016 VOL. 26, NOS. 4-5, 819-834 http://dx.doi.org/10.1080/10511482.2016.1193038 
Richmond, J. E. (1998). The mythical conception of rail transit in Los Angeles. Journal of Architectural and Planning Research, 15, 294-320.

Schneider, J. (2004). Public private partnership for urban rail transit: Forms, regulatory conditions, participants. Wiesbaden: Deutscher Universitäts-Verlag.

Sim, E., Krause, A., \& Winson-Geideman, K. (2015). The impact of transit-oriented development (TOD) on residential property prices: The case of Box Hill, Melbourne. Pacific Rim Property Research Journal, 21(3), 199-214.

doi:10.1080/14445921.2016.1140715

Smith, T. (2007). Edmonton's Suburban Explosion 1947-1969. Retrieved January 17, 2019, from http://capitalmodernedmonton.com/essay-troy-smith/

Statistics Canada. (2017). Focus on Geography Series, 2016 Census. Statistics Canada Catalogue no. 98-404-X2016001. Ottawa, Ontario. Data products, 2016 Census. Retrieved from https://www 12.statcan.gc.ca/census-recensement/2016/as-sa/fogs-spg/Facts-csd-eng.cfm? $\underline{\mathrm{LANG}}=\mathrm{Eng} \& \mathrm{GK}=\mathrm{CSD} \& \mathrm{GC}=4811061 \& \mathrm{TOPIC}=1$

Statistics Canada. (2018, February 13). Annual Demographic Estimates: Subprovincial Areas, July 1, 2017 Section 1: Census metropolitan areas. Retrieved November 9, 2018, from https://www150.statcan.gc.ca/n1/pub/91-214-x/2018000/section01-eng.htm

Stolte, E. (2017, April 05). Delayed Strathearn Heights project developer wants \$13-million deal before construction. Retrieved February 20, 2019, from https://edmontonjournal.com/news/local-news/delayed-strathearn-heights-project-develo per-wants-13-million-deal-before-construction

Stolte, E. (2017, August 16). Edmonton bets $\$ 1.8$ billion on LRT. Will private investment follow? Retrieved February 28, 2019, from https:/edmontonjournal.com/news/local-news/edmonton-bets-1-8-billion-on-lrt-will-priv ate-investment-follow

Tan, W., Bertolini, L., \& Janssen-Jansen, L. (2014). Identifying and conceptualising context-specific barriers to transit-oriented development strategies: The case of the Netherlands. Town Planning Review, 85(5), 639-663. doi:10.3828/tpr.2014.38

Transit Oriented Development Guidelines (2012, February). City of Edmonton. Retrieved November 9, 2018, from 
https://www.edmonton.ca/city_government/documents/PDF/TOD_Guidelines_-_Februar y_2012.pdf

Utter, M. A. (2009) Developing TOD in America: The Private Sector View. In C. Curtis, J. Rene \& L. Bertolini (Eds.), Transit Oriented Development: Making it Happen (pp. 209-224). Surrey: Ashgate Publishing Limited.

Vuchic, V. R. (2007). Urban transit: Systems and technology. Hoboken, NJ: J. Wiley \& Sons.

Wood, D. (2009). The Private Sector Perspective. In Living Cities (Eds.), Fostering Equitable and Sustainable Transit-Oriented Development Briefing Papers for a Convening on Transit-Oriented Development (pp. 37-42). http://iri.hks.harvard.edu/files/iri/files/fostering-equitable-and-sustainable-transit-oriented -development.pdf

Yang, P.P., \& Lew, S.H. (2009). An Asian Model of TOD: The Planning Integration in Singapore. In C. Curtis, J. Rene \& L. Bertolini (Eds.), Transit Oriented Development: Making it Happen (pp. 187-200). Surrey: Ashgate Publishing Limited.

Yaro, R. (2017, December 12). Governance Strategies To Achieve Transit-Oriented Development [Web log post]. Retrieved February 28, 2019, from https://www.citybuildinginstitute.ca/2017/12/12/governance-strategies-to-achieve-transitoriented-development/ 